\title{
GCU
}

Glasgow Caledonian

University

University for the Common Good

\section{Attributes and weights in health care priority setting: a systematic review of what counts and to what extent}

Gu, Yuanyuan; Lancsar, Emily; Ghijben, Peter; Butler, James R.G.; Donaldson, Cam

Published in:

Social Science and Medicine

DOI:

10.1016/j.socscimed.2015.10.005

Publication date:

2015

Link to publication in ResearchOnline

Citation for published version (Harvard):

Gu, Y, Lancsar, E, Ghijben, P, Butler, JRG \& Donaldson, C 2015, 'Attributes and weights in health care priority setting: a systematic review of what counts and to what extent', Social Science and Medicine, vol. 146, pp. 4152. https://doi.org/10.1016/j.socscimed.2015.10.005

\section{General rights}

Copyright and moral rights for the publications made accessible in the public portal are retained by the authors and/or other copyright owners and it is a condition of accessing publications that users recognise and abide by the legal requirements associated with these rights.

Take down policy

If you believe that this document breaches copyright please view our takedown policy at https://edshare.gcu.ac.uk/id/eprint/5179 for details of how to contact us. 


\section{Attributes and weights in health care priority setting: a systematic}

\section{review of what counts and to what extent}

Yuanyuan Gu' ${ }^{\mathrm{a}}$, Emily Lancsar ${ }^{\mathrm{a}}$, Peter Ghijben ${ }^{\mathrm{a}}$, Jim Butler ${ }^{\mathrm{b}}$, Cam Donaldson ${ }^{\mathrm{c}}$

a Centre for Health Economics, Monash Business School, Monash University, Level 2, Building 75, Clayton, Victoria 3800, Australia

b Australian Centre for Economic Research on Health (ACERH), Australian National University, Canberra, ACT 0200, Australia

c Yunus Centre for Social Business and Health, Glasgow Caledonian University, Level 3 Buchanan House, 58 Port Dundas Road, Glasgow, G4 0BA, United Kingdom

\section{Corresponding author:}

Yuanyuan $\mathrm{Gu}$,

Centre for Health Economics,

Level 2, Building 75 Monash University

Clayton, Victoria 3800, Australia

E-mail: yuanyuan.gu@monash.edu

Phone: +61 399058152

Fax: +61 399058344

\section{Acknowledgement}

The research was supported by a National Health and Medical Research Council (NHMRC) Project Grant (APP1047788): “Societal and decision maker preferences for priority setting in health care resource allocation”. We would like to thank Professor Jeffrey Richardson and the participants at the $36^{\text {th }}$ Australian Health Economics Society Conference and the International Priorities Conference 2014 for their helpful and valuable comments along with Brett Doble for useful advice. 


\section{Abstract}

In most societies resources are insufficient to provide everyone with all the health care they want. In practice, this means that some people are given priority over others. On what basis should priority be given? In this paper we are interested in the general public's views on this question. We set out to synthesis what the literature has found as a whole regarding which attributes or factors the general public think should count in priority setting and what weight they should receive. A systematic review was undertaken (in August 2014) to address these questions based on empirical studies that elicited stated preferences from the general public. Sixty four studies, applying eight methods, spanning five continents met the inclusion criteria. Discrete Choice Experiment (DCE) and Person Trade-off (PTO) were the most popular standard methods for preference elicitation, but only 34\% of all studies calculated distributional weights, mainly using PTO. While there is heterogeneity, results suggest the young are favoured over the old, the more severely ill are favoured over the less severely ill, and people with self-induced illness or high socioeconomic status tend to receive lower priority. In those studies that considered health gain, larger gain is universally preferred, but at a diminishing rate. Evidence from the small number of studies that explored preferences over different components of health gain suggests life extension is favoured over quality of life enhancement; however this may be reversed at the end of life. The majority of studies that investigated end of life care found weak/no support for providing a premium for such care. The review highlights considerable heterogeneity in both methods and results. Further methodological work is needed to achieve the goal of deriving robust distributional weights for use in health care priority setting. 


\section{Keywords}

Health care priority setting; Stated preferences; Distributional weights; Relative weights; DCE; PTO; Systematic review 


\section{Introduction}

Countries around the world face the question of how best to set priorities in the allocation of scarce health resources. Traditionally, economic evaluation has been adopted as the preferred approach to guide policy making in such decisions, with the quality-adjusted life year (QALY), a metric of health gain that combines both quality of life and length of life, being the mostcommonly adopted measure of the value of a health care treatment (Drummond, 2013; Hjelmgren, et al., 2001). However, evidence from studies involving members of the public in various countries (Stafinski, et al., 2011; Whitty, et al., 2014a), from studies of past health technology assessment (HTA) decisions (Clement, et al., 2009; Devlin and Parkin, 2004; Harris, et al., 2008) and from HTA guidelines (Canadian Agency for Drugs Technologies in Health, 2006; National Institute for Health and Clinical Excellence, 2008; Pharmaceutical Benefits Advisory Committee, 2013) suggests that QALY gain may not be the sole determinant of value.

A key question is therefore what additional factors the general public (whose taxes contribute to funding health care) find important in resource allocation decisions? A second question is what distributional (or relative) weights these factors should receive in priority setting. Such weights attach different (numerical) importance to QALYs based on the characteristics of the beneficiaries.

These two questions have been explored extensively in the health economics research literature (the first more so than the second). However, little is known about what the literature, as a whole, has found regarding which factors or attributes the general public think should count, and to what extent, in health resource allocation decisions.

This systematic review focuses on studies that have elicited stated preferences from the public as to what factors should count in allocating publicly-funded health care; and the weights to be attached to such factors. We address four questions: (1) which methods have been used to elicit 
stated preferences for attributes considered important in priority setting?; (2) which attributes arise out of the application of such methods?; (3) which methods have been used to elicit distributional weights?; and (4) what are the estimated distributional weights?

A small number of literature reviews on preferences in relation to priority setting have been conducted (Dolan, et al., 2005; Schwappach, 2002a; Shah, 2009; Stafinski, et al., 2011; Whitty, et al., 2014a; Youngkong, et al., 2009). In general they addressed our second question (an exception is Whitty, et al. (2014a) which also addressed our first question). However, to understand the differences between results about preferences it is necessary to understand how they were generated. Of importance too, after a large number of research studies, is whether a dominant approach has emerged for elicitation of preferences and weights, and whether a set of weights is ready for use in priority setting.

Thus, this paper contributes to the literature by, first, addressing new and important questions and, second, more completely addressing questions previously considered. In contrast to previous reviews, we consider a broader range of attributes and summarise them under three categories: (a) the characteristics of beneficiaries of the health gain/health care; (b) the characteristics of health gain; and (c) other important contextual factors. We highlight the degree of consensus amongst the literature and, wherever possible, identify possible reasons for differences. We focus on studies using samples representing the general public based on age and gender. Our review covers a broader range of methods and, importantly, compares results from different methods. It is also the first to classify the perspectives used in each study based on the six categories proposed by Dolan, et al. (2003).

\section{Methods}




\subsection{Overview}

PRISMA guidelines were used for the design of the review. The quality of studies included in the review was not evaluated because there is no single approach to assess the quality of the studies across the variety of methods used.

\subsection{Literature search}

Four databases were searched to ensure coverage across medicine and economics: Ovid Medline (1946 to present with daily update), Embase, Econlit and Web of Science (SCIexpanded and SSCI) from conception to 13 August 2014. Search terms were developed for two categories: health care priority setting (defined as setting priorities in the context of the allocation of publicly-funded health care) and preferences and were initially developed for the Ovid Medline database then modified for each database. Studies not reported in English were excluded from the review during screening and eligibility assessment. The complete search strategy, including search terms, for all four databases is in Supplementary Appendix 1. Additional studies were identified via a hand search of the references and citations from the included articles.

\subsection{Eligibility criteria}

Inclusion/exclusion criteria are in Table 1. Further to above, included studies were peer reviewed and must have involved elicitation of stated preferences between competing criteria, interventions, or patient groups applicable to priority setting for publicly-funded health care. Studies should not be disease or treatment specific in order to identify generic attributes, although some included studies provided clinical information merely as part of the question framing. Studies were excluded if their sample came from subgroups of the general public due to the focus on studies using samples representative of the general public, particularly in terms 
of age and gender. Studies using students do not provide such representativeness while those using small samples do. The inclusion/exclusion criteria were sequentially applied, starting with the language requirement and ending with the sample criterion.

\section{[INSERT TABLE 1]}

Two authors (YG and PG) independently screened the titles and abstracts of all studies identified from the search strategies. Full-texts of the studies included after the initial screening were also independently reviewed by these two authors. Discrepancies were resolved by discussion until a consensus was reached.

\subsection{Information extraction}

Data were extracted based on the four questions outlined in the introduction and also according to: (a) characteristics of beneficiaries of the health gain/health care; (b) characteristics of health gain; and (c) other important contextual factors. We note that classification into these three groups is subjective and other classifications are possible.

\section{Results}

\subsection{Overview}

The process of study selection is summarised in Figure 1. The database and hand searches initially identified 4,504 studies, with 64 papers included in the review. Table 2 documents the complete list of studies (and attributes explored in each). Their detailed summary are in Supplementary Appendix 2.

[INSERT FIGURE 1]

[INSERT TABLE 2] 
The 64 studies spanned over two decades from 1989 to 2014, Figure 2 revealing an increasing trend during this period. This may also reflect that earlier studies were excluded because they used non-representative samples of the general public. Studies were mostly carried out in the UK ( $n=20)$, the US ( $n=11)$, and Australia ( $n=9)$. Sample sizes varied from 23 to 17,657 with a median of 556. Around $70 \%$ of studies used a sample size larger than 200 , and $55 \%$ greater than 500 (See Supplementary Appendix 2).

[INSERT FIGURE 2]

\subsection{Methods for stated preference elicitation}

Eight preference elicitation methods have been used, which we categorise as choice based techniques or ranking based techniques (see Figure 3). Choice based approaches have dominated the literature (used 62 times in 60 of the 64 studies) with ranking tasks used in 4 studies. Within choice based approaches, DCE (including one best worst scaling study) has been used 17 times, PTO 15 times, choice tasks with bespoke design 15 times, simple choice tasks varying a single attribute 9 times, contingent valuation method (CVM) (or Willingness to Pay (WTP)) 5 times and a choice experiment with allocation of points once. The popularity of DCE has been increasing over time - 50\% of studies using DCE have been conducted in the past five years while only a third of the total PTO studies were undertaken during that time.

\section{[INSERT FIGURE 3]}

Following Dolan, et al. (2003), the perspective framing used in the included studies was classified based on (1) whom the respondent was asked to think about (personal, impartial decision maker (excluding self), citizen (including self)) and (2) the point in time at which the preference was elicited (ex post, ex ante). Most studies did not explicitly state the perspective used and thus classification was largely based on our interpretation. We identified 66 
perspectives from 63 studies (three studies included more than one perspective). One study did not provide any information about the question context so could not be classified (Lim, et al., 2012). Thirteen of 65 perspectives were classified as impartial decision maker, three as citizen and four as personal. The remaining 46 could be either impartial decision maker or citizen depending on how respondents interpreted the context - we classified this as (non-specific) social perspective. The most commonly used timing perspective was ex post (58 times), followed by ex ante (7 times). One study could not be classified due to inconsistent statements within the question context (Mortimer and Segal, 2008).

\subsection{Attributes and stated preferences}

In eliciting preferences, most studies attempted to control for confounding factors, either via wordings such as "all else being equal” or via explicitly fixing factors such as health gain and the cost of treatment. DCE studies typically included the health gain as an attribute.

\subsubsection{Characteristics of the beneficiaries}

Age

Twenty-five studies (39\%) elicited preferences for age. The majority (14 studies) suggest that the public in general favours the young over the elderly. However, preferences for age can be confounded by preferences for remaining life expectancy from a given age. If the confounding effect is controlled for, then the preference can be interpreted as preference for age per se; otherwise the preference for age may be conflated with preferences for remaining life expectancy. Among the 14 studies, eight controlled for the confounding effect (Dolan and Tsuchiya, 2005; Dolan and Tsuchiya, 2012; Johri, et al., 2009; Lewis and Charny, 1989; Nord, et al., 1996; Olsen, 2013; Schwappach and Strasmann, 2006; Tsuchiya, et al., 2003) while the 
remaining six did not. In the latter case, the young being favoured over the elderly might simply be a reflection of the general public’s preference for a person's capacity to benefit.

Another eight studies suggest that preferences for age display an inverted $U$ pattern, implying a person at working age is valued most (Baker, et al., 2010; Charny, et al., 1989; Cropper, et al., 1994; Diederich, et al., 2012; Jelsma, et al., 2002; Palanca-Tan, 2013; Petrou, et al., 2013; Whitty, et al., 2014b). Of these, five controlled for the confounding effect of remaining life expectancy (Baker, et al., 2010; Charny, et al., 1989; Jelsma, et al., 2002; Palanca-Tan, 2013; Petrou, et al., 2013) while the other three did not.

Discordant evidence comes from the remaining three studies. Diederich, et al. (2011) reported that age had little effect on health care priority setting while Linley and Hughes (2013) suggested that children were not favoured over adults. Both studies provided the option of equal allocation to different populations which was chosen by the majority of respondents. Lancsar, et al. (2011) found that age at onset and age at death if untreated had little effect and a very small effect respectively. This could be due to the fact that, unlike the majority of studies in the review, respondents were able to trade-off age against the size of the health gain and the resulting preference for the size of the health gain outweighed the preference for age. Both Linley and Hughes (2013) and Lancsar, et al. (2011) controlled for the confounding effect of remaining life expectancy while Diederich, et al. (2011) did not.

In total 15 studies controlled for the confounding effect of remaining life expectancy through four approaches: (1) four studies explicitly assumed the remaining life expectancy from current age is the same (Dolan and Tsuchiya, 2005; Johri, et al., 2009; Nord, et al., 1996; Olsen, 2013); (2) four studies used wordings such as "all else being equal” (Charny, et al., 1989; Lewis and Charny, 1989; Linley and Hughes, 2013; Palanca-Tan, 2013); (3) two considered age and the remaining life expectancy simultaneously (Lancsar, et al., 2011; Schwappach and Strasmann, 
2006); while (4) five studies explicitly stated in the survey that the preference is about a fixed number of years of life in full health (or a given quality of life (QoL)) at different ages (Baker, et al., 2010; Dolan and Tsuchiya, 2012; Jelsma, et al., 2002; Petrou, et al., 2013; Tsuchiya, et al., 2003).The remaining 10 studies did not control for the confounding effect of remaining life expectancy. Whether the preferences elicited in these studies are about age per se or about remaining life expectancy will depend on how respondents interpreted the question context and the assumptions they made..

Severity

Severity is included as a characteristic of the beneficiary since severity of an illness is experienced by the patient. Nineteen studies (30\%) elicited preferences for severity. There is considerable heterogeneity in the definitions of severity used in the literature. Table 3 documents the use of three types of severity related attributes. Not all 19 studies explicitly defined these attributes as severity but all three types have been explicitly defined as severity in the literature. The most popular definition is based on 'QoL if untreated'. Four studies also defined severity in terms of life expectancy (LE) if untreated (or age of onset and age of death if untreated) (Dolan and Tsuchiya, 2005; Lancsar, et al., 2011; Lim, et al., 2012; Whitty, et al., 2011). A number of studies loosely referred to pre-treatment health problems but did not describe the specific problems (Dolan and Shaw, 2003; Green, 2009; Green and Gerard, 2009; Linley and Hughes, 2013; Ryynanen, et al., 1996; Ubel, 1999; Winkelhage and Diederich, 2012).

\section{[INSERT TABLE 3]}

Nevertheless, the empirical evidence is consistent with 19 (out of 22) studies suggesting that members of the general public are in general willing to give priority to a patient with more 
severe disease. Among these studies, three further highlight that severity may be one of the most important attributes to use in health care priority setting: Dolan and Shaw (2003) and Diederich, et al. (2012) both ranked severity as the most important attribute and Linley and Hughes (2013) reported that 'more severely ill' was favoured regardless of size of health gain or cost of treatment.

Discordant evidence comes from the remaining three studies. Dolan and Tsuchiya (2005) and Lancsar, et al. (2011) found small or no effects of severity on priority setting with the small effect favouring the less severely ill. In the former, preference for severity is outweighed by the preference for the size of the health gain; in the latter respondents may be quite divided between favouring severe and less severe conditions, along with indifferent respondents. Ubel (1999) found that preferences for prioritising more severely ill patients were sensitive to the question framing.

\section{Lifestyle/Self-induced illness}

Ten studies (16\%) elicited preferences for lifestyle or self-induced illness. All suggest that the general public would give less priority to those considered in some way responsible for their ill health. However, Edlin, et al. (2012) found that this preference against self-induced illness was outweighed by the preference for prioritising the more severely ill.

\section{Socioeconomic status (SES)}

Ten studies (16\%) elicited preferences relating to beneficiaries' SES. Eight suggest that respondents tend to favour individuals with low SES over those with high SES. The other two suggest that people’s SES had little effect on priority setting (Charny, et al., 1989; Linley and Hughes, 2013). 


\section{Other attributes of beneficiaries}

Other attributes were explored by a relatively small number of studies, including having dependents, marital status, employment status, gender, indigenous people, QoL after treatment, treatment potential, rarity of disease, lifetime QALYs (i.e., health from a specific time to death), past QALYs (i.e., health experienced up to now), and past QoL (i.e., QoL of all the past years). Results are summarised in Supplementary Appendix 3.

\subsubsection{Characteristics of health gain}

\section{Size/distribution of the health gain}

Twenty three studies (36\%) elicited preferences for size or distribution of the health gain. Again there is heterogeneity in the definition of health gain used in the literature including: gain in life years; QoL; and QALYs. If QoL is fixed, gain in life years would imply gain in QALYs. However, when using gain in life years, studies in general did not assume QoL to be fixed. Larger gains are universally preferred over smaller gains and size of health gain was considered one of the most important attributes for health care priority setting in 3 studies (Dolan and Shaw, 2003; Lancsar, et al., 2011; Linley and Hughes, 2013).

Four studies suggest that the preference for larger gains may diminish as the size of gain increases (Lancsar, et al., 2011; Nord, et al., 1996; Norman, et al., 2013; Richardson, et al., 2011). This is in line with the finding of another six studies which suggest that people prefer to give small gains to many rather than large gains to a few (Gyrd-Hansen and Kristiansen, 2008; Olsen, 2000; Richardson, et al., 2012; Ubel, et al., 2001; Ubel, et al., 2000; Ubel, et al., 1996). However, Gyrd-Hansen and Kristiansen (2008) and Olsen (2000) found this preference for dispersion of gain over concentration happens only when the gain per person is greater than a certain threshold. 
Five studies (8\%) elicited preferences between prevention and cure. The majority suggest that prevention is preferred; the exception being Corso, et al. (2002) who found that cure was favoured over prevention based on median WTP estimates. During preference elicitation, all five studies kept the size of the health gain constant and all but Corso, et al. (2002) kept costs constant. However, WTP studies generally do not consider the costs of treatments. This may explain Corso, et al. (2002)'s unexpected result as some respondents may have thought cure is more costly than prevention and therefore were willing to pay more for an expensive good than for a cheap good.

Components of health gain

Five studies (8\%) elicited preferences for different components of health gain. Three components have been identified from the literature including the gain from QoL enhancement, from life extension, and from lifesaving (prevention of premature death). Results overall generally suggest gain from life extension is favoured over the gain from QoL enhancement (Olsen and Donaldson, 1998; Pennington, et al., 2013; Whitty, et al., 2014b). However, this preference may not apply to all life stages, e.g., at the very end of life, the gain from QoL improvement becomes more valuable than the gain from life extension (Pinto-Prades, et al., 2014; Shah, et al., 2014). Finally, Olsen and Donaldson (1998) showed that a lifesaving gain was valued much more highly than the other two types of health gain. Among the five studies, all but Whitty, et al. (2014b) fixed the size of the health gain, but none fixed the costs of treatments. Again, three were WTP studies which in general do not consider costs of treatments.

Other health gain attributes 
Two further attributes related to the characteristics of health gain have been explored: the timing of saving lives with Cropper, et al. (1994) finding people attach less importance to saving lives in the future than the present, and geographic equality of health gain distribution which was favoured by the respondents in a study by Quintal (2009).

\subsubsection{Other important contextual factors}

\section{Cost of treatment}

Eight studies (13\%) elicited preferences for the cost of treatment. The majority (five studies) suggest a preference for lower cost. However, two studies found higher cost was preferred (Linley and Hughes, 2013; Ryynanen, et al., 1996) and one found cost had little effect (Nord, et al., 1995). Plausible explanations have been offered for this surprising result: Ryynanen, et al. (1996) stated that respondents potentially associated expensive care with severe disease while Linley and Hughes (2013) suspected that the elicited preference related to a general preference for fairness in receiving treatment based on need. All but Ryynanen, et al. (1996) and Nord, et al. (1995) fixed the size of the health gain.

\section{Other contextual attributes}

Several other contextual factors were explored by a small number of studies. These include availability of alternative treatment, number of patients, chance of success, cost effectiveness, and uncertainty in evidence. Results are included in Supplementary Appendix 3.

\subsubsection{Cross-cutting attribute: end of life treatment}

End of life treatment is defined by the National Institute for Health and Care Excellence (NICE) as a treatment that meets three criteria based on life expectancy if untreated (less than 24 months), life expectancy gain from treatment (at least 3 months), and the size of patient 
population (small population) (National Institute for Health and Clinical Excellence, 2009). We single it out as a cross-cutting attribute since these criteria correspond to all three types of attributes: severity, size of health gain, and number of beneficiaries. Seven studies (11\%) elicited preferences for end of life treatment which, in most cases, has been defined using only the first two criteria. Evidence is mixed: five studies provide weak or no support for favouring such treatment while the other two suggest moderate support (Pennington, et al., 2013; PintoPrades, et al., 2014).

\subsection{Methods for elicitation of distributional weights}

Among those using samples drawn from the general public, only 22 studies (34\%) calculated distributional weights. Methods used to calculate relative weights included: PTO, DCE and social welfare function (SWF) based methods. Table 4 documents the 22 studies classified by methods and attributes.

\section{[INSERT TABLE 4]}

PTO was used in 15 studies. PTO asks respondents how many outcomes of one kind (condition A) are equivalent in social value to X outcomes of another kind (condition B). If one person's answer is $\mathrm{Y}$, then this individual's weight between condition $\mathrm{A}$ and $\mathrm{B}$ are $\mathrm{X} / \mathrm{Y}$ and 1 . Typically individual responses have been aggregated in two ways: the ratio of means (or medians); or the mean (or median) of the ratios (Baker, et al., 2010).

Five studies used the SWF based approach. Typically a certain type of SWF needs to be chosen, and then its parameters are assumed and/or estimated through a bespoke choice exercise (a factorial experimental design is typically not involved except in Palanca-Tan (2013)) which usually involves multiple groups of patients at different levels of one attribute (e.g., age, severity, social class) and with different aggregate health. The distributional weights for the 
attribute are estimated as the marginal rate of substitution between groups (Dolan and Tsuchiya, 2011).

Two studies derived weights using DCEs. Lancsar, et al. (2011) introduced a method based on the compensating variation to derive weights. In their study, two types of distributional weights were calculated: (1) weights for different levels of individual attributes and (2) weights for different combinations of attributes. Using the same DCE data, Baker, et al. (2010) also presented an approach called 'predicted probability of choice'. It produced somewhat larger weights compared to the compensating variation based approach. Finally, Norman, et al. (2013) used the marginal rate of substitution, to calculate weights for different combinations of attributes.

\subsection{Distributional weights}

Most distributional weights were elicited for age (11/22 studies that elicited weights) and severity (4/22 studies that elicited weights). These results are discussed here. Results for attributes other than age and severity are documented in Supplementary Appendix 2.

\section{Age}

Since the methods, attribute levels and question framings vary from study to study, it is challenging to synthesise and compare the distributional weights estimated from these studies. Nevertheless, the smallest weights are reported from a study using a DCE. In Lancsar, et al. (2011), the weights for age of onset were all close to 1, implying no weighting. Such weights are calculated by changing age of onset from its reference level of 40 years, while holding all other variables at their reference level (QoL lost=0.7, age of death=60 and QALY gain=4). While the authors do not state this in their paper, given they control for the confounding effect of remaining life expectancy, this suggests the elicited weights can be interpreted as weights 
for age per se. For age of death without treatment, higher weight was given to those who die young, aged 10 , or die old, aged 70 or 80 , although the weights remained relatively small. In contrast, the largest weights are reported from a study using PTO. In Johannesson and Johansson (1996), saving one person at age 30 was equivalent to saving 35 people at age 70, implying a weight of 35 to 1 between age 30 and 70. Apart from using different samples and sample sizes, there are two reasons that may explain this drastic difference. First, in Lancsar, et al. (2011) health gain is another attribute considered along with age and the analysis suggests that the choices were driven by the size of the health gain. Second, Johannesson and Johansson (1996) used a lifesaving context and did not explicitly fix the remaining life expectancy for patients of different ages. As previously discussed, respondents may conflate preferences for age per se and preferences for the remaining life expectancy in which case weights are more likely to represent the value of the remaining life expectancy from different ages rather than the value of one year in full health at different ages. Evidence suggests that the former may lead to larger weights favouring the young over the elderly than the latter (Jelsma, et al., 2002).

Severity

Compared to age weighting, an additional challenge to synthesise distributional weights for severity is that there is considerable heterogeneity in the definitions of severity used in the literature. Nevertheless, the smallest weights again come from a DCE study where significantly less weight (although still relatively close to 1) was given to the relatively more severe (Lancsar, et al., 2011). The largest weights are from a PTO study where saving one life was equivalent to returning 3 patients with severe health problems to full health (Nord, et al., 1993). The implied weights are 3 to 1 between saving a life and returning someone severely ill to full health.

\section{Discussions and conclusions}


This review has highlighted a large and increasing literature spanning five continents suggesting that the topic of preferences in relation to health care priority setting is highly relevant from an academic and policy perspective.

Empirical evidence has mainly focused on the characteristics of the recipients of health care and within this a particular focus on age and severity. Results generally suggest that the young are favoured over the old and the more severely ill are favoured over the less severely ill. There is evidence to suggest that people with self-induced illness or high SES should receive lower priority. Larger health gain is universally preferred, but potentially at a diminishing rate. These results are in general consistent with findings of past reviews. We also identified attributes that have previously been less explored. For example, a small number of studies suggest that life extension is favoured over QoL enhancement, although this preference may be reversed at the end of life. Also, our review suggests that, while in some jurisdictions higher weight is given to end of life treatment (National Institute for Health and Clinical Excellence, 2009), the majority of studies that investigated end of life care found weak/no support for providing a premium for such care.

This review is the first effort in the literature to review studies exploring distributional weights across a range of attributes. While 64 papers explored the broad topic of preferences for health care priority setting, only 34\% calculated distributional weights. Where weights were derived they generally focused on age and severity, despite evidence in this review that other characteristics of recipients of the health gain may be important as may the characteristics of the health gain itself or other contextual factors. Deriving weights for a broader set of characteristics would be a natural extension warranting further research. The variation in the magnitude of the distributional weights reported in the literature is very large, likely due to 
large heterogeneity in methods, contexts, countries/populations, sample sizes and the particular attributes (and their definitions) considered in the studies.

Eight different preference elicitation methods were used in the literature included in this review. There has been little consistency in methods although the majority of studies used a choice based approach with PTO and DCE being the most popular. Earlier in the literature PTO was the method most likely to be used but the more recent literature appears to be moving increasingly to using DCEs. DCEs have mainly been used to elicit preferences (usually investigated by examination of direction and significance of parameters estimated in the choice model). However, very few DCEs went on to derive distributional weights from the estimated choice models possibly because there has not been a standard method to derive weights. This would be a fruitful avenue for further research. In contrast, PTOs involve the direct elicitation of weights from which preferences are inferred. PTOs generally produced much larger distributional weights than DCEs. The focus in PTOs on single attributes one at a time rather than allowing trade-offs over multiple attributes could artificially inflate the resulting relative weights compared to DCEs which involve tradeoffs across multiple attributes simultaneously (Lancsar, et al., 2011). Similar results suggesting some strong isolated effects disappeared after the effects of additional attributes were taken into account were found by others using nonDCE and non-PTO methods (Edlin, et al., 2012; Linley and Hughes, 2013). However, this remains an unresolved issue. In light of the extreme differences in empirical results found from DCE and PTOs, sometimes even within the same study populations (Baker, et al., 2010), future work on theoretical and empirical reconciliation is important to ascertain the extent to which these differences are due to differences in preference elicitation methods and differences in actual preferences. 
While using different methods may explain a large part of the variation in the estimated distributional weights, substantial differences also exist among studies using the same approach. One possible reason is that, while these studies derive weights for similar attributes, there is heterogeneity in the definitions of these attributes. In the case of age weighting, there is a distinction between value of a year of life at different ages and value of the remaining life from different ages. The latter may lead to larger weights between young and old. Similarly, severity is the attribute with the least consensus regarding its definition and description to respondents. Regarding health gain, despite the literature often being couched in terms of distributional weights for QALYs, few studies defined the health gain attribute in terms of QALYs. Future consistency in terms of attribute descriptions may be warranted but should be balanced against the need to define attributes such that they allow investigation of the research questions at hand within each study. Another possible reason for the wide variation in weights is that even within the same approach, the method used to calculate weights can differ. For example, within DCE, based on very limited evidence, it seems the compensating variation, predicted probability and the marginal rate of substitution approaches may lead to different results.

A number of areas would benefit from future research. One is interactions between attributes and their effect on preferences for priority setting and distributional weights. Given the complex and multifaceted nature of priority setting, it may be that preferences for one attribute are influenced by preferences for another. For example, does the size of the health gain affect preferences for prioritising across severity? Interactions were rarely considered in the literature covered in this review (with two exceptions: Whitty, et al. (2014b) and Norman, et al. (2013) but are an important area warranting further research to uncover potentially important nuances in preferences and weights. 
A large subset of papers included in the review loosely refer to social value and social preferences. While such studies generally did not provide explicit definitions (an exception is Gyrd-Hansen \& Kristiansen, 2008), they loosely refer to social values or social preferences (and trade-offs between equity and efficiency) to distinguish such studies from individual preference based studies. When being asked to consider resource allocation within a publiclyfunded system, studies that referred to social preferences and values generally asked respondents to think about community (with or without themselves being included in that group), whereas studies eliciting individual preferences involved respondents thinking only about themselves. It is not surprising that concepts of social value and preferences have not been well defined in the studies in this review given the debate in the literature more generally regarding social choice theory (Arrow, et al., 2010). However, future research in this area would benefit from defining such concepts more explicitly, at least in the context of study objectives and the interpretation of results.

A related issue is the perspective used for preference elicitation in the context of health care priority setting at a government level. Framing of perspectives used was generally poorly expressed and in some circumstances inconsistent with the choice context described to respondents. As for the personal, impartial decision making or citizen, ex post or ex ante, which to use will largely depend on a study’s specific objective (Dolan, et al., 2003). Nevertheless, researchers are encouraged to distinguish these perspectives and to provide justification for their choices. Further research comparing the preferences and weights elicited from different perspectives is also warranted.

While important work has been undertaken to provide information on the general public's preferences in relation to health care priority setting, this review has highlighted a large degree of variation in both methods and empirical results. The literature seems to have converged 
towards DCE as a dominant approach to deriving preferences for priority setting in this area. However, the calculation of weights within DCE is in its infancy but represents a fruitful area for further research. Within this and other methods, it is important to account for the methodological issues noted above. Such methodological work would assist in achieving the goal of deriving robust distributional weights that could assist policy makers faced with the important challenge of prioritising the allocation of scarce health care resources.

\section{Reference}

Abasolo I, Tsuchiya A. 2004. Exploring social welfare functions and violation of monotonicity: An example from inequalities in health. Journal of Health Economics 23: 313-329.

Abásolo I, Tsuchiya A. 2013. Is more health always better for society? Exploring public preferences that violate monotonicity. Theory and decision 74: 539-563.

Arrow KJ, Sen A, Suzumura K. 2010. Handbook of social choice \& welfare. Elsevier:

Baker R, Bateman I, Donaldson C, Jones-Lee M, Lancsar E, Loomes G, et al. 2010. Weighting and valuing quality-adjusted life-years using stated preference methods: Preliminary results from the social value of a qaly project. Health Technology Assessment 14: 1-162.

Bleichrodt H, Doctor J, Stolk E. 2005. A nonparametric elicitation of the equity-efficiency trade-off in cost-utility analysis. Journal of Health Economics 24: 655-678.

Bosworth R, Cameron TA, DeShazo JR. 2010. Is an ounce of prevention worth a pound of cure? Comparing demand for public prevention and treatment policies. Medical Decision Making 30: E40-56.

Bryan S, Roberts T, Heginbotham C, McCallum A. 2002. Qaly-maximisation and public preferences: Results from a general population survey. Health Economics 11: 679-693.

Canadian Agency for Drugs Technologies in Health. 2006. Guidelines for the economic evaluation of health technologies: Canada. In Guidelines for the economic evaluation of health technologies: Canada. CADTH. 
Charny MC, Lewis PA, Farrow SC. 1989. Choosing who shall not be treated in the nhs. Social Science \& Medicine 28: 1331-1338.

Clement FM, Harris A, Li JJ, Yong K, Lee KM, Manns BJ. 2009. Using effectiveness and costeffectiveness to make drug coverage decisions: A comparison of britain, australia, and canada. Jama 302: 1437-1443.

Corso PS, Hammitt JK, Graham JD, Dicker RC, Goldie SJ. 2002. Assessing preferences for prevention versus treatment using willingness to pay. Medical Decision Making 22: S92-S101.

Cropper ML, Aydede SK, Portney PR. 1994. Preferences for life saving programs: How the public discounts time and age. Journal of risk and Uncertainty 8: 243-265.

Devlin N, Parkin D. 2004. Does nice have a cost - effectiveness threshold and what other factors influence its decisions? A binary choice analysis. Health economics 13: 437-452.

Diederich A, Swait J, Wirsik N. 2012. Citizen participation in patient prioritization policy decisions: An empirical and experimental study on patients' characteristics. Plos One 7.

Diederich A, Winkelhage J, Wirsik N. 2011. Age as a criterion for setting priorities in health care? A survey of the german public view. Plos One 6.

Dolan P, Olsen JA, Menzel P, Richardson J. 2003. An inquiry into the different perspectives that can be used when eliciting preferences in health. Health economics 12: 545-551.

Dolan P, Shaw R. 2003. A note on the relative importance that people attach to different factors when setting priorities in health care. Health Expectations 6: 53-59.

Dolan P, Shaw R, Tsuchiya A, Williams A. 2005. Qaly maximisation and people's preferences: A methodological review of the literature. Health Economics 14: 197-208.

Dolan P, Tsuchiya A. 2009. The social welfare function and individual responsibility: Some theoretical issues and empirical evidence. Journal of health economics 28: 210-220.

Dolan P, Tsuchiya A. 2005. Health priorities and public preferences: The relative importance of past health experience and future health prospects. Journal of Health Economics 24: 703-714. 
Dolan P, Tsuchiya A. 2012. It is the lifetime that matters: Public preferences over maximising health and reducing inequalities in health. Journal of Medical Ethics 38: 571-573.

Dolan P, Tsuchiya A. 2011. Determining the parameters in a social welfare function using stated preference data: An application to health. Applied Economics 43: 2241-2250.

Drummond M. 2013. Twenty years of using economic evaluations for drug reimbursement decisions: What has been achieved? Journal of health politics, policy and law 38: 1081-1102.

Edlin R, Tsuchiya A, Dolan P. 2012. Public preferences for responsibility versus public preferences for reducing inequalities. Health Economics 21: 1416-1426.

Eisenberg D, Freed GL, Davis MM, Singer D, Prosser LA. 2011. Valuing health at different ages: Evidence from a nationally representative survey in the us. Applied Health Economics and Health Policy 9: 149-156.

Green C. 2009. Investigating public preferences on 'severity of health' as a relevant condition for setting healthcare priorities. Social Science \& Medicine 68: 2247-2255.

Green C, Gerard K. 2009. Exploring the social value of health-care interventions: A stated preference discrete choice experiment. Health Economics 18: 951-976.

Gyrd-Hansen D. 2004. Investigating the social value of health changes. Journal of Health Economics 23: $1101-1116$.

Gyrd-Hansen D, Kristiansen IS. 2008. Preferences for 'life-saving' programmes: Small for all or gambling for the prize? Health Economics 17: 709-720.

Harris AH, Hill SR, Chin G, Li JJ, Walkom E. 2008. The role of value for money in public insurance coverage decisions for drugs in australia: A retrospective analysis 1994-2004. Medical Decision Making.

Hjelmgren J, Berggren F, Andersson F. 2001. Health economic guidelines-similarities, differences and some implications. Value in Health 4: 225-250. 
Jelsma J, Shumba D, Kristian H, De Weerdt W, De Cock P. 2002. Preferences of urban zimbabweans for health and life lived at different ages. Bulletin of the World Health Organization 80: 204209.

Johannesson M, Johansson P-O. 1996. The economics of ageing: On the attitude of swedish people to the distribution of health care resources between the young and the old. Health Policy 37: 153-161.

Johannesson M, Johansson P-O. 1997. Is the valuation of a qaly gained independent of age? Some empirical evidence. Journal of Health Economics 16: 589-599.

Johri M, Damschroder L, Zikmund-Fisher B, Kim S, Ubel P. 2009. Can a moral reasoning exercise improve response quality to surveys of healthcare priorities? Journal of Medical Ethics 35: 57-64.

Lancsar E, Wildman J, Donaldson C, Ryan M, Baker R. 2011. Deriving distributional weights for qalys through discrete choice experiments. Journal of Health Economics 30: 466-478.

Lewis P, Charny M. 1989. Which of two individuals do you treat when only their ages are different and you can't treat both? Journal of Medical Ethics 15: 28-34.

Lim MK, Bae EY, Choi SE, Lee EK, Lee TJ. 2012. Eliciting public preference for health-care resource allocation in south korea. Value in Health 15: S91-S94.

Linley WG, Hughes DA. 2013. Societal views on nice, cancer drugs fund and value-based pricing criteria for prioritising medicines: A cross-sectional survey of 4118 adults in great britain. Health Economics 22: 948-964.

Mortimer D, Segal L. 2008. Is the value of a life or life-year saved context specific? Further evidence from a discrete choice experiment. Cost Effectiveness and Resource Allocation 6.

National Institute for Health and Clinical Excellence. 2008. Social value judgements: Principles for the development of nice guidance.

National Institute for Health and Clinical Excellence. Appraising life-extending, end of life treatments. NICE: London, 2009. 
Nord E, Richardson J, Macarounas-Kirchmann K. 1993. Social evaluation of health care versus personal evaluation of health states: Evidence on the validity of four health-state scaling instruments using norwegian and australian surveys. International Journal of Technology Assessment in Health Care 9: 463-478.

Nord E, Richardson J, Street A, Kuhse H, Singer P. 1995. Who cares about cost? Does economic analysis impose or reflect social values? Health Policy 34: 79-94.

Nord E, Street A, Richardson J, Kuhse H, Singer P. 1996. The significance of age and duration of effect in social evaluation of health care. Health Care Analysis 4: 103-111.

Norman R, Hall J, Street D, Viney R. 2013. Efficiency and equity: A stated preference approach. Health Economics 22: 568-581.

Olsen J. 2013. Priority preferences:"End of life" does not matter, but total life does. Value in Health 16: 1063.

Olsen JA. 2000. A note on eliciting distributive preferences for health. Journal of Health Economics 19: 541-550.

Olsen JA, Donaldson C. 1998. Helicopters, hearts and hips: Using willingness to pay to set priorities for public sector health care programmes. Social Science \& Medicine 46: 1-12.

Palanca-Tan R. 2013. Age preferences for life-saving programs: Using choice modeling to measure the relative values of statistical life. The Singapore Economic Review $\mathbf{5 8 .}$

Pennington M, Baker R, Brouwer W, Mason H, Hansen DG, Robinson A, et al. 2013. Comparing wtp values of different types of qaly gain elicited from the general public. Health Economics 24: 280-293.

Petrou S, Kandala NB, Robinson A, Baker R. 2013. A person trade-off study to estimate age-related weights for health gains in economic evaluation. Pharmacoeconomics 31: 893-907.

Pharmaceutical Benefits Advisory Committee. 2013. Guidelines for preparing submissions to the pharmaceutical benefits advisory committee (version 4.3). Canberra: Australian Government Department of Health and Ageing. 
Pinto-Prades J-L, Sánchez-Martínez F-I, Corbacho B, Baker R. 2014. Valuing qalys at the end of life. Social Science \& Medicine 113: 5-14.

Quintal C. 2009. Aversion to geographic inequality and geographic variation in preferences in the context of healthcare. Applied Health Economics and Health Policy 7: 121-136.

Richardson J, Sinha K, lezzi A, Maxwell A. 2012. Maximising health versus sharing: Measuring preferences for the allocation of the health budget. Social Science \& Medicine 75: 13511361.

Richardson JR, McKie J, Peacock SJ, lezzi A. 2011. Severity as an independent determinant of the social value of a health service. The European Journal of Health Economics 12: 163-174.

Roberts T, Bryan S, Heginbotham C, McCallum A. 1999. Public involvement in health care priority setting: An economic perspective. Health Expectations 2: 235-244.

Ryynanen OP, Myllykangas M, Vaskilampi T, Takala J. 1996. Random paired scenarios-a method for investigating attitudes to prioritisation in medicine. Journal of Medical Ethics 22: 238-242.

Schwappach DL. 2002a. Resource allocation, social values and the qaly: A review of the debate and empirical evidence. Health Expectations 5: 210-222.

Schwappach DL. 2002b. The equivalence of numbers: The social value of avoiding health decline: An experimental web-based study. BMC medical informatics and decision making 2: 3.

Schwappach DL, Strasmann TJ. 2006. "Quick and dirty numbers"? The reliability of a statedpreference technique for the measurement of preferences for resource allocation. Journal of Health Economics 25: 432-448.

Shah KK. 2009. Severity of illness and priority setting in healthcare: A review of the literature. Health Policy 93: 77-84.

Shah KK, Tsuchiya A, Wailoo AJ. 2014. Valuing health at the end of life: An empirical study of public preferences. The European Journal of Health Economics 15: 389-399.

Shiroiwa T, Igarashi A, Fukuda T, Ikeda S. 2013. Wtp for a qaly and health states: More money for severer health states? Cost Effectiveness and Resource Allocation 11: 22. 
Singh J, Lord J, Longworth L, Orr S, McGarry T, Sheldon R, et al. 2012. Does responsibility affect the public's valuation of health care interventions? A relative valuation approach to health care safety. Value in Health 15: 690-698.

Stafinski T, Menon D, Marshall D, Caulfield T. 2011. Societal values in the allocation of healthcare resources. The Patient: Patient-Centered Outcomes Research 4: 207-225.

Tsuchiya A, Dolan P. 2007. Do nhs clinicians and members of the public share the same views about reducing inequalities in health? Social Science \& Medicine 64: 2499-2503.

Tsuchiya A, Dolan P, Shaw R. 2003. Measuring people's preferences regarding ageism in health: Some methodological issues and some fresh evidence. Social Science \& Medicine 57: 687696.

Ubel PA. 1999. How stable are people's preferences for giving priority to severely ill patients? Social Science \& Medicine 49: 895-903.

Ubel PA, Baron J, Asch DA. 2001. Preference for equity as a framing effect. Medical Decision Making 21: 180-189.

Ubel PA, Baron J, Nash B, Asch DA. 2000. Are preferences for equity over efficiency in health care allocation "all or nothing"? Medical Care 38: 366-373.

Ubel PA, DeKay ML, Baron J, Asch DA. 1996. Cost-effectiveness analysis in a setting of budget constraints-is it equitable? New England Journal of Medicine 334: 1174-1177.

Ubel PA, Richardson J, Prades JLP. 1999. Life-saving treatments and disabilities - are all qalys created equal? International Journal of Technology Assessment in Health Care 15: 738-748.

Ubel PA, Spranca MD, DeKay ML, Hershey JC, Asch DA. 1997. Public preferences for prevention versus cure: What if an ounce of prevention is worth only an ounce of cure? Medical Decision Making 18: 141-148.

Whitty JA, Lancsar E, Rixon K, Golenko X, Ratcliffe J. 2014a. A systematic review of stated preference studies reporting public preferences for healthcare priority setting. The Patient: PatientCentered Outcomes Research 7: 365-386. 
Whitty JA, Ratcliffe J, Chen G, Scuffham PA. 2014b. Australian public preferences for the funding of new health technologies: A comparison of discrete choice and profile case best-worst scaling methods. Medical Decision Making 34: 638-654.

Whitty JA, Rundle-Thiele SR, Scuffham PA. 2008. Insights into public preferences for pharmaceutical funding. International Journal of Pharmaceutical and Healthcare Marketing 2: 216-234.

Whitty JA, Scuffham PA, Rundle-Thielee SR. 2011. Public and decision maker stated preferences for pharmaceutical subsidy decisions. Applied health economics and health policy 9: 73-79.

Winkelhage J, Diederich A. 2012. The relevance of personal characteristics in allocating health care resources-controversial preferences of laypersons with different educational backgrounds. International Journal of Environmental Research and Public Health 9: 223-243.

Youngkong S, Kapiriri L, Baltussen R. 2009. Setting priorities for health interventions in developing countries: A review of empirical studies. Tropical Medicine \& International Health 14: 930939. 
Table 1 Inclusion and exclusion criteria for the literature review

\begin{tabular}{|c|c|c|}
\hline & Inclusion criteria & Exclusion criteria \\
\hline Language & -English & - Not in English \\
\hline Publication & - Peer reviewed & - Not peer reviewed \\
\hline Context & $\begin{array}{l}\text { - Stated preferences } \\
\text { - Health care setting } \\
\text { - Include competing criteria, } \\
\text { interventions, or patients in a } \\
\text { general setting } \\
\text { - Applicable to priority setting for } \\
\text { publically-funded health care }\end{array}$ & $\begin{array}{l}\text { - Revealed preferences } \\
\text { - Non health care setting } \\
\text { - Criteria, interventions, or patients in a } \\
\text { specific setting (e.g. HIV/AIDS, } \\
\text { organ transplantation, informal/formal } \\
\text { services) } \\
\text { - Broad or narrow priority setting level } \\
\text { (e.g. global priorities, priorities within } \\
\text { a healthcare facility) }\end{array}$ \\
\hline Data & -Empirical studies & $\begin{array}{l}\text { - Other studies (e.g. theoretical studies, } \\
\text { editorials, review articles) }\end{array}$ \\
\hline Methods & $\begin{array}{l}\text { - Quantitative methods for trade- } \\
\text { offs (e.g. choice-based methods, } \\
\text { person trade-off methods, and } \\
\text { ranking or rating exercises). }\end{array}$ & $\begin{array}{l}\text { - Qualitative methods (e.g. focus } \\
\text { groups and structured interviews, } \\
\text { percentage agreement with a } \\
\text { statement). }\end{array}$ \\
\hline Sample & - General public & $\begin{array}{l}\text { - Subgroups of the general public (e.g. } \\
\text { patients, clinicians, gender, specific } \\
\text { age) } \\
\text { - Health technology assessment } \\
\text { decision makers }\end{array}$ \\
\hline
\end{tabular}


Table 2 Attributes explored in each study

\begin{tabular}{|c|c|c|c|c|c|c|c|c|c|c|c|c|}
\hline Study & Age & Severity & $\begin{array}{l}\text { Lifestyle/Self- } \\
\text { induced illness }\end{array}$ & SES & $\begin{array}{l}\text { Other attributes of } \\
\text { beneficiaries }\end{array}$ & $\begin{array}{l}\text { Size/distrib } \\
\text { ution of } \\
\text { health gain }\end{array}$ & $\begin{array}{l}\text { Prevention } \\
\text { vs cure }\end{array}$ & $\begin{array}{l}\text { Components } \\
\text { of health gain }\end{array}$ & $\begin{array}{l}\text { Other health } \\
\text { gain attributes }\end{array}$ & $\begin{array}{l}\text { Cost of } \\
\text { treatment }\end{array}$ & $\begin{array}{c}\text { Other contextual } \\
\text { attributes }\end{array}$ & End of life \\
\hline $\begin{array}{l}\text { Abasolo and } \\
\text { Tsuchiya } \\
(2004)\end{array}$ & & & & $\checkmark$ & & & & & & & & \\
\hline $\begin{array}{l}\text { Abásolo and } \\
\text { Tsuchiya } \\
\text { (2013) }\end{array}$ & & & & $\checkmark$ & & & & & & & & \\
\hline $\begin{array}{c}\text { Baker, et al. } \\
(2010)\end{array}$ & $\checkmark$ & $\checkmark$ & & & & & & & & & & \\
\hline $\begin{array}{l}\text { Bleichrodt, et } \\
\text { al. (2005) }\end{array}$ & & & & & Lifetime QALYs & & & & & & & \\
\hline $\begin{array}{l}\text { Bosworth, et } \\
\text { al. (2010) }\end{array}$ & & & & & & $\checkmark$ & $\checkmark$ & & & & & \\
\hline $\begin{array}{l}\text { Bryan, et al. } \\
(2002)\end{array}$ & & & & & QoL after treatment & $\checkmark$ & & & & & $\begin{array}{l}\text { Number of patients, } \\
\text { Chance of success }\end{array}$ & \\
\hline $\begin{array}{l}\text { Charny, et al. } \\
\text { (1989) }\end{array}$ & $\checkmark$ & & $\checkmark$ & $\checkmark$ & $\begin{array}{c}\text { Marital status, } \\
\text { Employment status, } \\
\text { Gender }\end{array}$ & & & & & & & \\
\hline $\begin{array}{c}\text { Corso, et al. } \\
(2002)\end{array}$ & & & & & & & $\checkmark$ & & & & & \\
\hline $\begin{array}{l}\text { Cropper, et } \\
\text { al. (1994) }\end{array}$ & $\checkmark$ & & & & & & & & $\begin{array}{c}\text { Timing of saving } \\
\text { lives }\end{array}$ & & & \\
\hline $\begin{array}{l}\text { Diederich, et } \\
\text { al. (2012) }\end{array}$ & $\checkmark$ & $\checkmark$ & $\checkmark$ & $\checkmark$ & $\begin{array}{l}\text { Having dependents, } \\
\text { Marital status }\end{array}$ & & & & & & & \\
\hline $\begin{array}{l}\text { Diederich, et } \\
\text { al. (2011) }\end{array}$ & $\checkmark$ & & & & & & & & & & & \\
\hline $\begin{array}{c}\text { Dolan and } \\
\text { Shaw (2003) }\end{array}$ & & $\checkmark$ & $\checkmark$ & & Having dependents & $\checkmark$ & & & & & & \\
\hline $\begin{array}{l}\text { Dolan and } \\
\text { Tsuchiya } \\
(2005)\end{array}$ & $\checkmark$ & $\checkmark$ & & & Past QoL & & & & & & & \\
\hline $\begin{array}{l}\text { Dolan and } \\
\text { Tsuchiya } \\
(2009)\end{array}$ & & & $\checkmark$ & & & & & & & & & \\
\hline $\begin{array}{l}\text { Dolan and } \\
\text { Tsuchiya } \\
\text { (2011) }\end{array}$ & & & & $\checkmark$ & & & & & & & & \\
\hline $\begin{array}{l}\text { Dolan and } \\
\text { Tsuchiya } \\
(2012)\end{array}$ & $\checkmark$ & & & & Past QALYs & & & & & & & \\
\hline
\end{tabular}




\begin{tabular}{|c|c|c|c|c|c|c|c|c|c|c|c|c|}
\hline Study & Age & Severity & $\begin{array}{l}\text { Lifestyle/Self- } \\
\text { induced illness }\end{array}$ & SES & $\begin{array}{c}\text { Other attributes of } \\
\text { beneficiaries }\end{array}$ & $\begin{array}{c}\text { Size/distrib } \\
\text { ution of } \\
\text { health gain }\end{array}$ & $\begin{array}{l}\text { Prevention } \\
\text { vs cure }\end{array}$ & $\begin{array}{l}\text { Components } \\
\text { of health gain }\end{array}$ & $\begin{array}{l}\text { Other health } \\
\text { gain attributes }\end{array}$ & $\begin{array}{c}\text { Cost of } \\
\text { treatment }\end{array}$ & $\begin{array}{c}\text { Other contextual } \\
\text { attributes }\end{array}$ & End of life \\
\hline $\begin{array}{l}\text { Edlin, et al. } \\
\text { (2012) }\end{array}$ & & & $\checkmark$ & & Lifetime QALYs & & & & & & & \\
\hline $\begin{array}{l}\text { Eisenberg, et } \\
\text { al. (2011) }\end{array}$ & $\checkmark$ & & & & & & & & & & & \\
\hline Green (2009) & & $\checkmark$ & & $\checkmark$ & & & & & & & & \\
\hline $\begin{array}{l}\text { Green and } \\
\text { Gerard } \\
(2009)\end{array}$ & & $\checkmark$ & & & & $\checkmark$ & & & & & $\begin{array}{c}\text { Availability of } \\
\text { alternative treatment, } \\
\text { Cost effectiveness }\end{array}$ & \\
\hline $\begin{array}{l}\text { Gyrd-Hansen } \\
\text { (2004) }\end{array}$ & & $\checkmark$ & & & & & & & & & & \\
\hline $\begin{array}{l}\text { Gyrd-Hansen } \\
\text { and } \\
\text { Kristiansen } \\
\text { (2008) }\end{array}$ & & & & & & $\checkmark$ & & & & & & \\
\hline $\begin{array}{l}\text { Jelsma, et al. } \\
\text { (2002) }\end{array}$ & $\checkmark$ & & & & & & & & & & & \\
\hline $\begin{array}{l}\text { Johannesson } \\
\text { and Johansson } \\
(1996) \\
\end{array}$ & $\checkmark$ & & & & & & & & & & & \\
\hline $\begin{array}{c}\text { Johannesson } \\
\text { and Johansson } \\
\text { (1997) }\end{array}$ & $\checkmark$ & & & & & & & & & & & \\
\hline $\begin{array}{l}\text { Johri, et al. } \\
\text { (2009) }\end{array}$ & $\checkmark$ & & & & & & & & & & & \\
\hline $\begin{array}{l}\text { Lancsar, et al. } \\
\text { (2011) }\end{array}$ & $\checkmark$ & $\checkmark$ & & & & $\checkmark$ & & & & & & $\checkmark$ \\
\hline $\begin{array}{l}\text { Lewis and } \\
\text { Charny } \\
(1989) \\
\end{array}$ & $\checkmark$ & & & & & & & & & & & \\
\hline $\begin{array}{l}\text { Lim, et al. } \\
\text { (2012) }\end{array}$ & & $\checkmark$ & & $\checkmark$ & & $\checkmark$ & & & & & & \\
\hline $\begin{array}{l}\text { Linley and } \\
\text { Hughes } \\
(2013) \\
\end{array}$ & $\checkmark$ & $\checkmark$ & & $\checkmark$ & $\begin{array}{l}\text { Having dependents, } \\
\text { Rarity of disease }\end{array}$ & $\checkmark$ & & & & $\checkmark$ & $\begin{array}{c}\text { Availability of } \\
\text { alternative treatment }\end{array}$ & $\checkmark$ \\
\hline $\begin{array}{l}\text { Mortimer and } \\
\text { Segal (2008) }\end{array}$ & $\checkmark$ & & $\checkmark$ & & & $\checkmark$ & $\checkmark$ & & & $\checkmark$ & Uncertainty in evidence & \\
\hline $\begin{array}{c}\text { Nord, et al. } \\
\text { (1993) }\end{array}$ & & $\checkmark$ & & & & & & & & & & \\
\hline $\begin{array}{l}\text { Nord, et al. } \\
\text { (1995) }\end{array}$ & & & & & & & & & & $\checkmark$ & & \\
\hline
\end{tabular}




\begin{tabular}{|c|c|c|c|c|c|c|c|c|c|c|c|c|}
\hline Study & Age & Severity & $\begin{array}{l}\text { Lifestyle/Self- } \\
\text { induced illness }\end{array}$ & SES & $\begin{array}{l}\text { Other attributes of } \\
\text { beneficiaries }\end{array}$ & $\begin{array}{c}\text { Size/distrib } \\
\text { ution of } \\
\text { health gain }\end{array}$ & $\begin{array}{l}\text { Prevention } \\
\text { vs cure }\end{array}$ & $\begin{array}{l}\text { Components } \\
\text { of health gain }\end{array}$ & $\begin{array}{l}\text { Other health } \\
\text { gain attributes }\end{array}$ & $\begin{array}{c}\text { Cost of } \\
\text { treatment }\end{array}$ & $\begin{array}{c}\text { Other contextual } \\
\text { attributes }\end{array}$ & End of life \\
\hline $\begin{array}{c}\text { Nord, et al. } \\
\text { (1996) }\end{array}$ & $\checkmark$ & & & & & $\checkmark$ & & & & & & \\
\hline $\begin{array}{l}\text { Norman, et } \\
\text { al. (2013) }\end{array}$ & & & $\checkmark$ & $\checkmark$ & Having dependents & $\checkmark$ & & & & & & \\
\hline Olsen (2000) & & & & & & $\checkmark$ & & & & & & \\
\hline Olsen (2013) & $\checkmark$ & & & & & $\checkmark$ & & & & & & $\checkmark$ \\
\hline $\begin{array}{c}\text { Olsen and } \\
\text { Donaldson } \\
\text { (1998) }\end{array}$ & & & & & & & & $\checkmark$ & & & & \\
\hline $\begin{array}{l}\text { Palanca-Tan } \\
\text { (2013) }\end{array}$ & $\checkmark$ & & & & & $\checkmark$ & & & & & Number of patients & \\
\hline $\begin{array}{l}\text { Pennington, et } \\
\text { al. (2013) }\end{array}$ & & & & & & & & $\checkmark$ & & & & $\checkmark$ \\
\hline $\begin{array}{l}\text { Petrou, et al. } \\
\text { (2013) }\end{array}$ & $\checkmark$ & & & & & & & & & & & \\
\hline $\begin{array}{l}\text { Pinto-Prades, } \\
\text { et al. (2014) }\end{array}$ & & & & & & & & $\checkmark$ & & & & $\checkmark$ \\
\hline $\begin{array}{l}\text { Quintal } \\
\text { (2009) }\end{array}$ & & & & & & & & & $\begin{array}{c}\text { Geographic } \\
\text { equality }\end{array}$ & & & \\
\hline $\begin{array}{l}\text { Richardson, } \\
\text { et al. (2012) }\end{array}$ & & & & & & $\checkmark$ & & & & & & \\
\hline $\begin{array}{l}\text { Richardson, } \\
\text { et al. (2011) }\end{array}$ & & $\checkmark$ & & & & $\checkmark$ & & & & & & \\
\hline $\begin{array}{l}\text { Roberts, et al. } \\
\text { (1999) }\end{array}$ & & & & & QoL after treatment & & & & & & & \\
\hline $\begin{array}{l}\text { Ryynanen, et } \\
\text { al. (1996) }\end{array}$ & $\checkmark$ & $\checkmark$ & $\checkmark$ & & & & & & & $\checkmark$ & & \\
\hline $\begin{array}{l}\text { Schwappach } \\
\text { (2002b) }\end{array}$ & & & & & & & $\checkmark$ & & & & & \\
\hline $\begin{array}{l}\text { Schwappach } \\
\text { and } \\
\text { Strasmann } \\
\text { (2006) }\end{array}$ & $\checkmark$ & $\checkmark$ & & & Rarity of disease & $\checkmark$ & & & & $\checkmark$ & & \\
\hline $\begin{array}{l}\text { Shah, et al. } \\
\text { (2014) }\end{array}$ & & & & & & & & $\checkmark$ & & & & $\checkmark$ \\
\hline $\begin{array}{l}\text { Shiroiwa, et } \\
\text { al. (2013) }\end{array}$ & & $\checkmark$ & & & & & & & & & & $\checkmark$ \\
\hline $\begin{array}{l}\text { Singh, et al. } \\
\text { (2012) }\end{array}$ & & & $\checkmark$ & & & & & & & & & \\
\hline $\begin{array}{l}\text { Tsuchiya and } \\
\text { Dolan (2007) }\end{array}$ & & & & $\checkmark$ & & & & & & & & \\
\hline
\end{tabular}




\begin{tabular}{|c|c|c|c|c|c|c|c|c|c|c|c|c|}
\hline Study & Age & Severity & $\begin{array}{l}\text { Lifestyle/Self- } \\
\text { induced illness }\end{array}$ & SES & $\begin{array}{c}\text { Other attributes of } \\
\text { beneficiaries }\end{array}$ & $\begin{array}{c}\text { Size/distrib } \\
\text { ution of } \\
\text { health gain }\end{array}$ & $\begin{array}{c}\text { Prevention } \\
\text { vs cure }\end{array}$ & $\begin{array}{l}\text { Components } \\
\text { of health gain }\end{array}$ & $\begin{array}{c}\text { Other health } \\
\text { gain attributes }\end{array}$ & $\begin{array}{c}\text { Cost of } \\
\text { treatment }\end{array}$ & $\begin{array}{c}\text { Other contextual } \\
\text { attributes }\end{array}$ & End of life \\
\hline $\begin{array}{l}\text { Tsuchiya, et } \\
\text { al. (2003) }\end{array}$ & $\checkmark$ & & & & & & & & & & & \\
\hline Ubel (1999) & & $\checkmark$ & & & & & & & & & & \\
\hline $\begin{array}{l}\text { Ubel, et al. } \\
\text { (2001) }\end{array}$ & & & & & & $\checkmark$ & & & & & & \\
\hline $\begin{array}{l}\text { Ubel, et al. } \\
(2000)\end{array}$ & & & & & & $\checkmark$ & & & & & & \\
\hline $\begin{array}{l}\text { Ubel, et al. } \\
\text { (1996) }\end{array}$ & & & & & & $\checkmark$ & & & & & & \\
\hline $\begin{array}{l}\text { Ubel, et al. } \\
\text { (1999) }\end{array}$ & & & & & Treatment potential & & & & & & & \\
\hline $\begin{array}{l}\text { Ubel, et al. } \\
\text { (1997) }\end{array}$ & & $\checkmark$ & & & & & $\checkmark$ & & & & & \\
\hline $\begin{array}{l}\text { Whitty, et al. } \\
\text { (2014a) }\end{array}$ & $\checkmark$ & & & & Indigenous people & & & $\checkmark$ & & & $\begin{array}{c}\text { Availability of } \\
\text { alternative treatment, } \\
\text { Number of patients, Cost } \\
\text { effectiveness }\end{array}$ & \\
\hline $\begin{array}{l}\text { Whitty, et al. } \\
\text { (2008) }\end{array}$ & & & & & QoL after treatment & $\checkmark$ & & & & $\checkmark$ & Chance of success & \\
\hline $\begin{array}{l}\text { Whitty, et al. } \\
\text { (2011) }\end{array}$ & & $\checkmark$ & & & & $\checkmark$ & & & & $\checkmark$ & Chance of success & \\
\hline $\begin{array}{l}\text { Winkelhage } \\
\text { and Diederich } \\
\text { (2012) }\end{array}$ & $\checkmark$ & $\checkmark$ & $\checkmark$ & & & $\checkmark$ & & & & $\checkmark$ & & \\
\hline
\end{tabular}

Note:

(1) SES: socioeconomic status

(2) QoL: Quality of life 
Table 3 Descriptions of severity and frequency of use

\begin{tabular}{|l|c|c|}
\hline \multicolumn{1}{|c|}{ Severity description } & Frequency & Percentage \\
\hline $\begin{array}{l}\text { QoL } \\
\text { untreated) }\end{array}$ & 12 & 52 \\
\hline Pre-treatment health problems, not clearly defined & 7 & 30 \\
\hline LE if untreated ${ }^{(2)}$ & 4 & 17 \\
\hline Total & 23 & 100 \\
\hline
\end{tabular}

Note:

(1) QoL means 'quality of life'.

(2) LE means 'life expectancy'; Lancsar, et al. (2011) included LE implicitly via age of onset and age of death.

(3) Several studies used more than one severity related attributes so the frequency of use here adds up to more than 19. 
Table 4 Distributional weights classified by attributes and methods

\begin{tabular}{|c|c|c|c|c|c|c|c|c|c|}
\hline \multirow{2}{*}{ Study } & \multicolumn{3}{|c|}{ Age } & \multicolumn{3}{|c|}{ Severity } & \multicolumn{3}{|c|}{ Other attributes } \\
\hline & PTO & DCE & SWF & PTO & DCE & SWF & PTO & DCE & SWF \\
\hline Baker, et al. (2010) & $\checkmark$ & $\checkmark$ & & $\checkmark$ & $\checkmark$ & & & & \\
\hline Cropper, et al. (1994) & $\checkmark$ & & & & & & & & \\
\hline Eisenberg, et al. (2011) & $\checkmark$ & & & & & & & & \\
\hline Jelsma, et al. (2002) & $\checkmark$ & & & & & & & & \\
\hline Johannesson and Johansson (1996) & $\checkmark$ & & & & & & & & \\
\hline Johannesson and Johansson (1997) & $\checkmark$ & & & & & & & & \\
\hline Nord, et al. (1993) & & & & $\checkmark$ & & & & & \\
\hline Nord, et al. (1996) & $\checkmark$ & & & & & & & & \\
\hline Petrou, et al. (2013) & $\checkmark$ & & & & & & & & \\
\hline Pinto-Prades, et al. (2014) & & & & & & & End of life & & \\
\hline Quintal (2009) & & & & & & & $\begin{array}{c}\text { Geographic equality of health } \\
\text { gain distribution }\end{array}$ & & \\
\hline Richardson, et al. (2011) & & & & $\checkmark$ & & & & & \\
\hline Schwappach (2002b) & & & & & & & Prevention vs cure & & \\
\hline Singh, et al. (2012) & & & & & & & Lifestyle & & \\
\hline Ubel, et al. (1999) & & & & & & & Treatment potential & & \\
\hline Bleichrodt, et al. (2005) & & & & & & & & & Lifetime QALYs \\
\hline Dolan and Tsuchiya (2009) & & & & & & & & & $\begin{array}{l}\text { Self-induced } \\
\text { illness } \\
\end{array}$ \\
\hline Dolan and Tsuchiya (2011) & & & & & & & & & SES \\
\hline Dolan and Tsuchiya (2012) & & & $\checkmark$ & & & & & & Past QALYs \\
\hline Palanca-Tan (2013) & & & $\checkmark$ & & & & & & \\
\hline Lancsar, et al. (2011) & & $\checkmark$ & & & $\checkmark$ & & & $\begin{array}{l}\text { Combination of several } \\
\text { attributes including health gain }\end{array}$ & \\
\hline Norman, et al. (2013) & & & & & & & & $\begin{array}{l}\text { Combination of several } \\
\text { attributes including health gain }\end{array}$ & \\
\hline
\end{tabular}

Note: (1) PTO: Person trade-off ; (2) DCE: Discrete choice experiment; (3) SWF: Social welfare function; (4) SES: Socioeconomic status 
Figure 1 Flow diagram for selection of studies

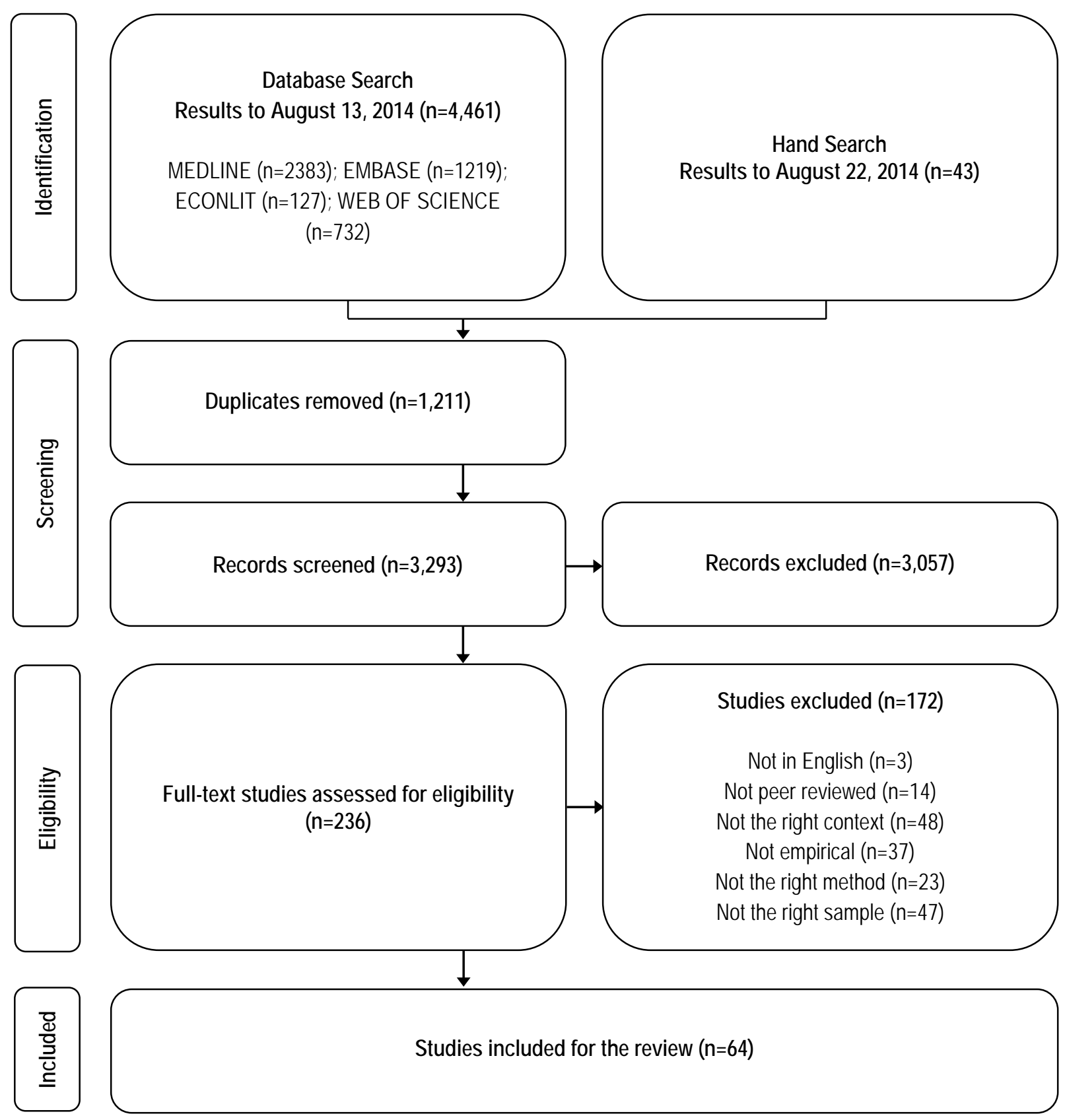


Figure 2 Number of studies per year from 1989 to August 2014

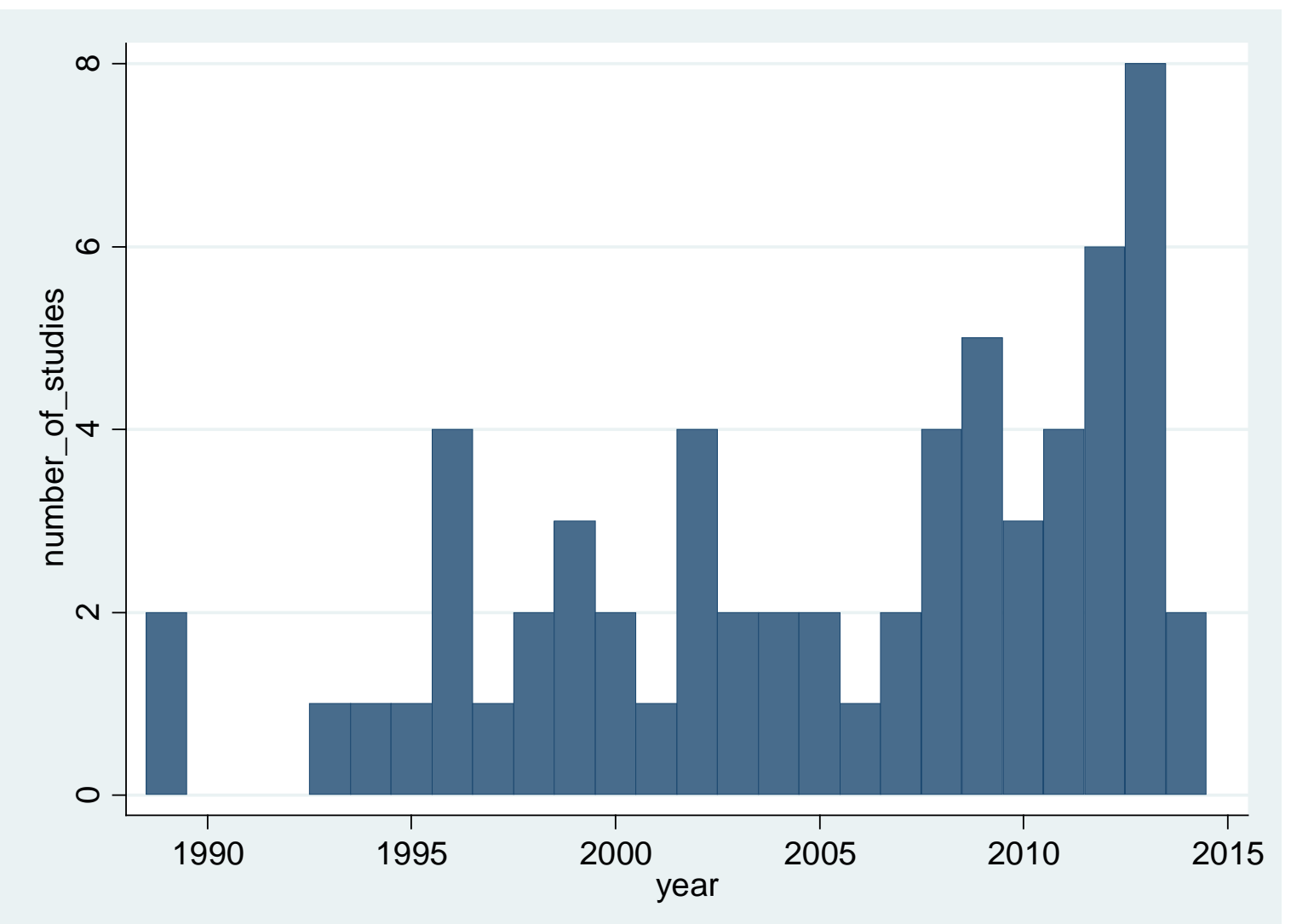


Figure 3 Categorisation of methods for preference elicitation

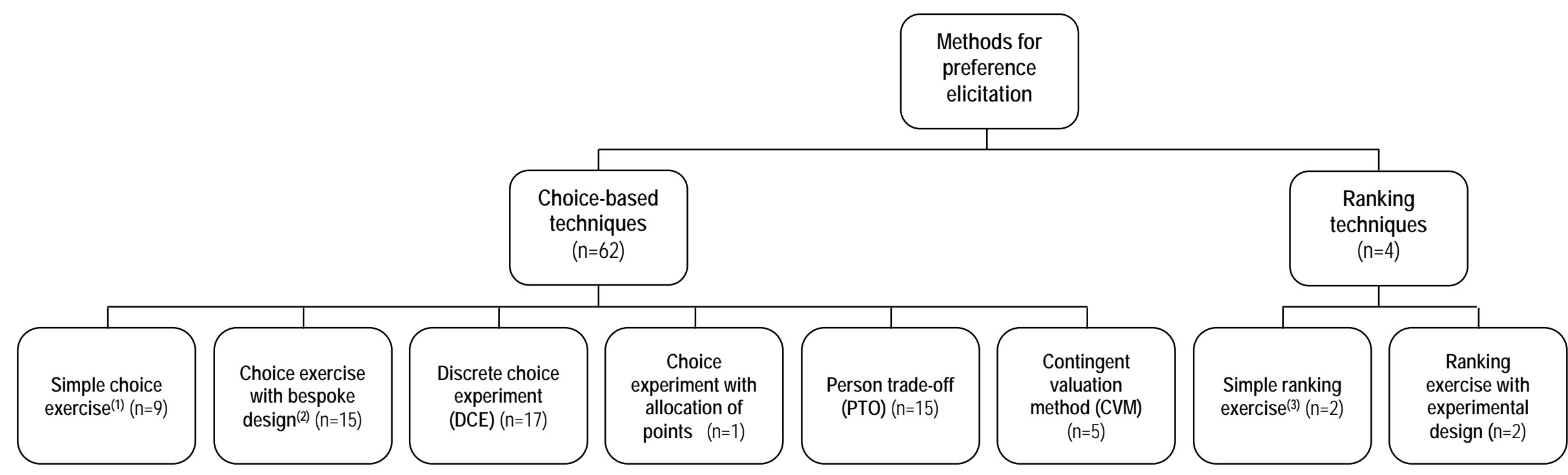

Note:

(1) Studies using simple choice exercise present respondents with scenarios that vary with respect to one attribute, and ask them to choose or allocate points between them. This category includes studies where the dependent variable is discrete choice or allocation of points.

(2) Studies using choice exercise with bespoke design typically involve multiple attributes and are designed to address specific hypotheses or theories without the use of a factorial experimental design.

(3) Simple ranking exercise ranks a list of attributes based on their relative importance.

(4) Frequency of use for each method is recorded in brackets. Whitty, et al. (2014b) used both DCE and BWS, and Pinto-Prades, et al. (2014) used both PTO and CVM. Hence, the numbers add up to 66 instead of 64 . 


\section{Appendix 1 Complete search strategy}

Database: Ovid MEDLINE, searched on 13 Aug, 2014

\begin{tabular}{|c|c|c|}
\hline \multirow{2}{*}{$\begin{array}{l}\text { Database } \\
\text { Search No }\end{array}$} & \multicolumn{2}{|l|}{ Ovid MEDLINE(R) 1946 to Present with Daily Update } \\
\hline & Searches & Results \\
\hline 1 & exp resource allocation/ or exp health care rationing/ & 15526 \\
\hline 2 & exp Health Priorities/ & 8892 \\
\hline 3 & (health care or healthcare).ti,ab. & 295660 \\
\hline 4 & (resource $\$$ adj5 allocation).ti,ab. & 7424 \\
\hline 5 & (priorit\$ adj5 set\$).ti,ab. & 3289 \\
\hline 6 & 3 and 4 & 2196 \\
\hline 7 & 3 and 5 & 927 \\
\hline 8 & exp Technology Assessment, Biomedical/ & 9262 \\
\hline 9 & (health technolog\$ adj5 assessment\$).ti,ab. & 1880 \\
\hline 10 & exp Drug Approval/ec, mt [Economics, Methods] & 1055 \\
\hline 11 & (reimbursement adj5 decision\$).ti,ab. & 430 \\
\hline 12 & (coverage adj5 decision\$).ti,ab. & 525 \\
\hline 13 & (public insurance adj5 coverage\$).ti,ab. & 57 \\
\hline 14 & cost effectiveness threshold\$.ti,ab. & 253 \\
\hline 15 & 1 or 2 or 6 or 7 or 8 or 9 or 10 or 11 or 12 or 13 or 14 & 36876 \\
\hline 16 & preference\$.ti,ab. & 88016 \\
\hline 17 & relative importance.ti,ab. & 12932 \\
\hline 18 & (tradeoff\$ or trade off\$).ti,ab. & 12549 \\
\hline 19 & league table\$.ti,ab. & 228 \\
\hline 20 & (multi-criteria or multiple-criteria) .ti,ab. & 832 \\
\hline
\end{tabular}




\begin{tabular}{|c|l|r|}
\hline 21 & exp Social Values/ & 18989 \\
\hline 22 & social value\$.ti,ab. & 917 \\
\hline 23 & societal value\$.ti,ab. & 263 \\
\hline 24 & distributional weight\$.ti,ab. & 22 \\
\hline 25 & equity weight\$.ti,ab. & 3102 \\
\hline 26 & relative weight\$.ti,ab. & 1087 \\
\hline 27 & (QALY\$ adj5 maximi\$).ti,ab. & 900 \\
\hline 28 & (health adj5 maximi\$).ti,ab. & 136739 \\
\hline 29 & value for money.ti,ab. & 2310 \\
\hline 30 & $\begin{array}{l}16 \text { or } 17 \text { or } 18 \text { or } 19 \text { or } 20 \text { or } 21 \text { or } 22 \text { or } 23 \text { or } 24 \text { or } 25 \text { or } 26 \\
\text { or } 27 \text { or } 28 \text { or } 29\end{array}$ \\
\hline 31 & 15 and 30 & \\
\hline 32 & $\begin{array}{l}\text { limit } 31 \text { to humans } \\
\text { Outcome }\end{array}$ & 2383 hits \\
\hline
\end{tabular}


Database: EMBASE, searched on 13 Aug, 2014

\begin{tabular}{|c|c|c|}
\hline Database & \multicolumn{2}{|l|}{ EMBASE } \\
\hline Search No & Searches & Results \\
\hline 1 & 'health care' & 1181803 \\
\hline 2 & 'healthcare' & 428490 \\
\hline 3 & \#1 OR \#2 & 1477019 \\
\hline 4 & priori* NEAR/5 set* & 5104 \\
\hline 5 & resource* NEAR/5 allocation & 22520 \\
\hline 6 & rationing & 2793 \\
\hline 7 & \#3 AND \#4 & 2455 \\
\hline 8 & \#3 AND \#5 & 13860 \\
\hline 9 & \#3 AND \#6 & 2337 \\
\hline 10 & 'health technology assessment' & 4847 \\
\hline 11 & 'health technology assessments' & 428 \\
\hline 12 & 'drug approval’ & 27653 \\
\hline 13 & reimbursement NEAR/5 decision* & 957 \\
\hline 14 & coverage NEAR/5 decision* & 791 \\
\hline 15 & 'public insurance coverage' & 43 \\
\hline 16 & 'cost effectiveness threshold' & 363 \\
\hline 17 & 'cost effectiveness thresholds' & 148 \\
\hline 18 & $\begin{array}{l}\text { \#7 OR \#8 OR \#9 OR \#10 OR \#11 OR \#12 OR \#13 OR \#14 } \\
\text { OR \#15 OR \#16 OR \#17 }\end{array}$ & 51774 \\
\hline 19 & preference* & 123200 \\
\hline 20 & 'relative importance' & 15837 \\
\hline 21 & tradeoff* OR 'trade off' OR 'trade offs' & 15922 \\
\hline 22 & 'league table’ OR ‘league tables’ & 299 \\
\hline
\end{tabular}




\begin{tabular}{|c|c|c|}
\hline 23 & 'multi-criteria' OR 'multiple-criteria' & 1322 \\
\hline 24 & 'social value' OR 'social values' & 1214 \\
\hline 25 & 'societal value' OR 'societal values' & 363 \\
\hline 26 & 'distributional weight' OR 'distributional weights' & 8 \\
\hline 27 & 'equity weight' OR 'equity weights' & 18 \\
\hline 28 & 'relative weight' OR 'relative weights' & 3606 \\
\hline 29 & qaly* NEAR/5 maximi* & 65 \\
\hline 30 & health NEAR/5 maximi* & 1814 \\
\hline 31 & 'value for money' & 1342 \\
\hline 32 & $\begin{array}{l}\# 19 \text { OR \#20 OR \#21 OR \#22 OR \#23 OR \#24 OR \#25 OR } \\
\# 26 \text { OR \#27 OR \#28 OR \#29 OR \#30 OR \#31 }\end{array}$ & 161893 \\
\hline 33 & \#18 AND \#32 & 1647 \\
\hline 34 & \#33 AND [humans]/lim & 1219 \\
\hline Outcome & 1219 hits & \\
\hline
\end{tabular}


Database: ECONLIT, searched on 13 Aug, 2014

\begin{tabular}{|l|l|}
\hline \multicolumn{1}{|c|}{ Database } & \multicolumn{1}{c|}{ Econlit (via EBSCOhost) } \\
\hline Search syntax & $\begin{array}{l}\text { ( ( ("health care" OR healthcare) AND (priorit* N5 set* OR resource* N5 } \\
\text { allocation OR rationing) ) OR ( health technolog* N5 assessment* OR drug* N5 } \\
\text { approval OR reimbursement N5 decision* OR coverage N5 decision* OR "public } \\
\text { insurance coverage" OR "cost effectiveness threshold*" ) ) AND ( preference* OR } \\
\text { "relative importance" OR tradeoff* OR "trade off*" OR "league table*" OR } \\
\text { "multi-criteria" OR "multiple-criteria" OR "social value*" OR "societal value*" } \\
\text { OR "distributional weight*" OR "equity weight*" OR "relative weight*" OR } \\
\text { QALY* N5 maximi* OR health N5 maximi* OR "value for money" ) }\end{array}$ \\
\hline Outcome & 127 hits \\
\hline
\end{tabular}


Database: WEB OF SCIENCE (SCI-EXPANDED \& SSCI), searched on 13 Aug, 2014

\begin{tabular}{|c|c|c|}
\hline Database & WEB OF SCIENCE & \\
\hline Search No & Searches & Results \\
\hline 1 & TS=(healthcare OR "health care") & 255941 \\
\hline 2 & $\mathrm{TS}=($ priorit* NEAR/5 set*) & 5256 \\
\hline 3 & TS=(resource* NEAR/5 allocation) & 23089 \\
\hline 4 & $\mathrm{TS}=($ rationing $)$ & 22299 \\
\hline 5 & \#4 OR \#3 OR \#2 & 49932 \\
\hline 6 & \#5 AND \#1 & 3988 \\
\hline 7 & TS=("health technology assessment*") & 1905 \\
\hline 8 & TS=("drug approval") & 806 \\
\hline 9 & TS=(reimbursement NEAR/5 decision*) & 486 \\
\hline 10 & $\mathrm{TS}=($ coverage NEAR/5 decision*) & 725 \\
\hline 11 & TS=("public insurance coverage" ) & 37 \\
\hline 12 & TS=("cost effectiveness threshold*") & 251 \\
\hline 13 & \#12 OR \#11 OR \#10 OR \#9 OR \#8 OR \#7 OR \#6 & 7846 \\
\hline 14 & TS=(preference $*$ ) & 199455 \\
\hline 15 & TS=("relative importance" ) & 31097 \\
\hline 16 & TS=(tradeoff* OR "trade off*") & 61920 \\
\hline 17 & TS=("league table*") & 540 \\
\hline 18 & TS=("multi-criteria" OR "multiple-criteria") & 8210 \\
\hline 19 & TS=("social value*" OR "societal value*" ) & 3527 \\
\hline 20 & $\begin{array}{l}\text { TS=( "distributional weight*" OR "equity weight*" OR "relative } \\
\text { weight*") }\end{array}$ & 5101 \\
\hline 21 & TS=(QALY* NEAR/5 maximi*) & 43 \\
\hline
\end{tabular}




\begin{tabular}{|c|l|r|}
\hline 22 & TS=(health NEAR/5 maximi*) & 1082 \\
\hline 23 & TS=(“value for money”) & 1255 \\
\hline 24 & $\begin{array}{l}\text { \#23 OR \#22 OR \#21 OR \#20 OR \#19 OR \#18 OR \#17 OR \#16 OR } \\
\text { \#15 OR \#14 }\end{array}$ & 304024 \\
\hline 25 & \#24 AND \#13 & 732 \\
\hline Outcome & 732 hits & \\
\hline
\end{tabular}




\section{Appendix 2 Summary of included studies}

\begin{tabular}{|c|c|c|c|c|c|c|}
\hline Study & Country & Sample & Perspective & Method & Attributes/ Stated Preferences & Distributional weights \\
\hline $\begin{array}{l}\text { Abasolo and } \\
\text { Tsuchiya } \\
\text { (2004) }\end{array}$ & Spain & $\begin{array}{l}973 \text { respondents from } \\
\text { Spain }\end{array}$ & $\begin{array}{c}\text { Social } \\
\text { non-specific } \\
\text { / ex post }\end{array}$ & $\begin{array}{l}\text { choice exercise with } \\
\text { bespoke design }\end{array}$ & social class: low > high & \\
\hline $\begin{array}{l}\text { Abasolo and } \\
\text { Tsuchiya } \\
\text { (2013) }\end{array}$ & Spain & $\begin{array}{l}1013 \text { respondents from } \\
\text { Spain }\end{array}$ & $\begin{array}{c}\text { Impartial } \\
\text { decision } \\
\text { maker / ex } \\
\text { post }\end{array}$ & $\begin{array}{l}\text { choice exercise with } \\
\text { bespoke design }\end{array}$ & social class: low > high & \\
\hline $\begin{array}{l}\text { Baker et al. } \\
\text { (2009) }\end{array}$ & UK & $\begin{array}{l}587 \text { respondents } \\
\text { representative of } \\
\text { England population }\end{array}$ & $\begin{array}{c}\text { Social } \\
\text { non-specific } \\
\text { / ex post }\end{array}$ & $\begin{array}{l}\text { PTO (DCE is the same } \\
\text { as Lancsar et al. } \\
(2011))\end{array}$ & $\begin{array}{l}\text { (1) age: overall the young are favored over } \\
\text { the old; } 20-40 \text { years > 40-60 years }>0-20 \\
\text { years > 60-80 years } \\
\text { (2) severity: not the most severe condition } \\
\text { gets priority; instead, it is ranked among the } \\
\text { lowest }\end{array}$ & $\begin{array}{l}\text { Using the 'ratio of mean' method: } \\
\text { age weights(average over severity) } \\
\text { for } 0-20,20-40,40-60,60-80 \text { years } \\
\text { are } 0.775,1,0.814,0.527 \\
\text { severity weights (average over age) } \\
\text { for } 0->20 \%, 20 \%->40 \% \text {, } \\
40 \%->60 \%, 60 \%->80 \% \text {, } \\
80 \%->100 \% \text { are } 0.791,1,0.876, \\
0.848,0.688\end{array}$ \\
\hline
\end{tabular}




\begin{tabular}{|c|c|c|c|c|c|c|}
\hline $\begin{array}{l}\text { Bleichrodt et } \\
\text { al. (2005) }\end{array}$ & $\begin{array}{l}\text { The } \\
\text { Netherlands }\end{array}$ & $\begin{array}{l}179 \text { respondents from } \\
\text { the Dutch population }\end{array}$ & $\begin{array}{l}\text { Impartial } \\
\text { decision } \\
\text { maker / ex } \\
\text { post }\end{array}$ & $\begin{array}{l}\text { choice exercise with } \\
\text { bespoke design; } \\
\text { weights estimated } \\
\text { using the social welfare } \\
\text { function based method }\end{array}$ & $\begin{array}{l}\text { expected lifetime QALYs: a new born with } \\
\text { smaller lifetime QALYs is favored over a } \\
\text { new born with larger lifetime QALYs }\end{array}$ & $\begin{array}{l}\text { reported for different number of } \\
\text { expected lifetime QALYs (see table } \\
7 \text { in Bleichrodt et al. (2005)) }\end{array}$ \\
\hline $\begin{array}{l}\text { Bosworth et } \\
\text { al. (2010) }\end{array}$ & US & $\begin{array}{l}1500 \text { respondents each } \\
\text { for two surveys, } \\
\text { nationally } \\
\text { representative }\end{array}$ & $\begin{array}{c}\text { Social } \\
\text { non-specific } \\
\text { / ex post }\end{array}$ & DCE & $\begin{array}{l}\text { (1) number of illnesses prevented or number } \\
\text { of recoveries increased: its marginal utility } \\
\text { from prevention policies is the same as the } \\
\text { one from treatment policies } \\
\text { (2) number of deaths avoided: its marginal } \\
\text { utility from prevention policies is about } \\
\text { twice as much as the one from treatment } \\
\text { policies } \\
\text { Both attributes have significant positive } \\
\text { effects. }\end{array}$ & \\
\hline $\begin{array}{l}\text { Bryan et al. } \\
\text { (2002) }\end{array}$ & UK & $\begin{array}{l}909 \text { respondents from } \\
\text { Hertfordshire, highly } \\
\text { representative of local } \\
\text { population }\end{array}$ & $\begin{array}{c}\text { Social } \\
\text { non-specific } \\
\text { / ex post }\end{array}$ & DCE & $\begin{array}{l}\text { (1) number of people } \\
\text { (2) chance of success } \\
\text { (3) LE after treatment } \\
\text { (4) QOL after treatment } \\
\text { All have significant positive effects. }\end{array}$ & \\
\hline
\end{tabular}




\begin{tabular}{|c|c|c|c|c|c|c|}
\hline $\begin{array}{l}\text { Charny et al. } \\
\text { (1989) }\end{array}$ & UK & $\begin{array}{l}\text { a random sample of } \\
719 \text { respondents from } \\
\text { Cardiff }\end{array}$ & $\begin{array}{c}\text { Social } \\
\text { non-specific } \\
\text { / ex post }\end{array}$ & simple choice exercise & $\begin{array}{l}\text { (1) age: young children are less valuable } \\
\text { than older children, but elderly people are } \\
\text { less valued than young people } \\
\text { (2) lifestyle/culpability: healthy > not } \\
\text { healthy, inherited disease > self-induced } \\
\text { disease } \\
\text { (3) social class: no effect (significant } \\
\text { minority prefers a director over a person } \\
\text { without skills, a teacher over a lorry driver) } \\
\text { (4) employment status: no effect (significant } \\
\text { minority prefers employed over } \\
\text { unemployed) } \\
\text { (5) gender: no effect (significant minority } \\
\text { prefer female over male) } \\
\text { (6) marital status: married > single }\end{array}$ & \\
\hline $\begin{array}{l}\text { Corso et al. } \\
\text { (2002) }\end{array}$ & US & $\begin{array}{l}1104 \text { English-speaking } \\
\text { US adults }\end{array}$ & $\begin{array}{l}\text { Personal / ex } \\
\text { post }\end{array}$ & CVM & $\begin{array}{l}\text { prevention vs treatment: the former's WTP is } \\
\text { larger ( } \$ 665 \text { vs } \$ 223 \text { ) }\end{array}$ & \\
\hline $\begin{array}{l}\text { Cropper et } \\
\text { al. (1994) }\end{array}$ & US & $\begin{array}{l}1000 \text { households in } \\
\text { Maryland (Maryland } \\
\text { Poll), } 564 \text { households } \\
\text { in the Washington D.C. } \\
\text { metropolitan area, and } \\
\text { a random sample of } \\
1000 \text { households }\end{array}$ & $\begin{array}{c}\text { Social } \\
\text { non-specific } \\
\text { / ex post }\end{array}$ & PTO & $\begin{array}{l}\text { (1) timing of health gain: today }>\text { future } \\
\text { (2) age: the young are favoured over the old } \\
\text { with a peak of age-related preference for } \\
\text { patients aged around } 28\end{array}$ & $\begin{array}{l}\text { For the median respondent, the } \\
\text { weights for life saving in } 100 \text { years, } \\
\text { in } 25 \text { years, and today are } 1 / 45,1 / 6 \text {, } \\
\text { and } 1 \text {; the weights for life saving at } \\
20,30,40 \text {, and } 60 \text { years old are } 8 \text {, } \\
11,7 \text {, and } 1 \text {. }\end{array}$ \\
\hline
\end{tabular}




\begin{tabular}{|c|c|c|c|c|c|}
\hline $\begin{array}{l}\text { Diederich et } \\
\text { al. (2011) }\end{array}$ & Germany & $\begin{array}{l}2031 \text { respondents } \\
\text { representative of the } \\
\text { German adult } \\
\text { population }\end{array}$ & $\begin{array}{c}\text { Social } \\
\text { non-specific } \\
\text { / ex post }\end{array}$ & $\begin{array}{l}\text { simple choice exercise } \\
\text { (DCE is the same as } \\
\text { Diederich et al. (2012)) }\end{array}$ & $\begin{array}{l}\text { age: little evidence that the German public } \\
\text { accepts age as a criterion to prioritize health } \\
\text { care services (strong evidence from DCE by } \\
\text { contrast) }\end{array}$ \\
\hline $\begin{array}{l}\text { Diederich et } \\
\text { al. (2012) }\end{array}$ & Germany & $\begin{array}{l}2031 \text { respondents } \\
\text { representative of the } \\
\text { adult population of } \\
\text { Germany }\end{array}$ & $\begin{array}{c}\text { Social } \\
\text { non-specific } \\
\text { / ex post }\end{array}$ & DCE & $\begin{array}{l}\text { Mean preferences: } \\
\text { (1) health status: severe disease > light } \\
\text { disease } \\
\text { (2) quality of life: severely restricted > } \\
\text { restricted > no restrictions } \\
\text { (3) unhealthy life style: yes > no } \\
\text { (4) age of patient: } 43>25>68>87 \\
\text { (5) family status: single with dependents > } \\
\text { single without dependents >= couple with } \\
\text { dependents > couple without dependents } \\
\text { (6) occupational status: low > medium > } \\
\text { high } \\
\text { Relative importance: } \\
\text { (1) health status ( 50\%) } \\
\text { (2) quality of life (24.7\%) } \\
\text { (3) age (12\%) } \\
\text { (4) family status (7.9\%) } \\
\text { (5) occupational status (4.6\%) } \\
\text { (6) unhealthy lifestyle (0.8\%) }\end{array}$ \\
\hline
\end{tabular}




\begin{tabular}{|c|c|c|c|c|c|c|}
\hline $\begin{array}{l}\text { Dolan and } \\
\text { Shaw (2003) }\end{array}$ & UK & $\begin{array}{l}\text { a representative sample } \\
\text { of } 23 \text { from York }\end{array}$ & $\begin{array}{c}\text { Social } \\
\text { non-specific } \\
\text { / ex post }\end{array}$ & simple ranking exercise & $\begin{array}{l}\text { no-treatment profile }>\text { health gain }>\text { time } \\
\text { spent waiting for treatment }>\text { lifestyle } \\
\text { choices }>\text { previous health profile }>\text { impact } \\
\text { on others }>\text { claims based on compensation or } \\
\text { reward }\end{array}$ & \\
\hline $\begin{array}{l}\text { Dolan and } \\
\text { Tsuchiya } \\
\text { (2005) }\end{array}$ & UK & $\begin{array}{l}100 \text { respondents from } \\
\text { Yorkshire and } \\
\text { Humberside }\end{array}$ & $\begin{array}{c}\text { Social } \\
\text { non-specific } \\
\text { / ex post }\end{array}$ & $\begin{array}{l}\text { ranking exercise with } \\
\text { experimental design }\end{array}$ & $\begin{array}{l}\text { (1) age: } 40 \text { > } 60 \\
\text { (2) severity: mixed results based on different } \\
\text { severity measures: } \\
\text { past health (QOL without condition): mixed } \\
\text { - it had a significant effect in the context of } \\
\text { imminence of death, but was not significant } \\
\text { in the context of severity of health } \\
\text { future LE without treatment: statistically } \\
\text { insignificant } \\
\text { future QOL without treatment: statistically } \\
\text { insignificant } \\
\text { age is the most important factor }\end{array}$ & \\
\hline $\begin{array}{l}\text { Dolan and } \\
\text { Tsuchiya } \\
\text { (2009) }\end{array}$ & UK & $\begin{array}{l}\text { a random sample of } \\
130 \text { respondents from } \\
\text { York }\end{array}$ & $\begin{array}{c}\text { Social } \\
\text { non-specific } \\
\text { / ex post }\end{array}$ & $\begin{array}{l}\text { choice exercise with } \\
\text { bespoke design; } \\
\text { weights estimated } \\
\text { using the social welfare } \\
\text { function based method }\end{array}$ & $\begin{array}{l}\text { self-induced/unhealthy lifestyle: significant } \\
\text { negative }\end{array}$ & $\begin{array}{l}\text { respondents wanted to give people } \\
\text { who have not cared for their own } \\
\text { health about half as much weight as } \\
\text { those who have cared for their } \\
\text { health }\end{array}$ \\
\hline
\end{tabular}




\begin{tabular}{|c|c|c|c|c|c|c|}
\hline $\begin{array}{l}\text { Dolan and } \\
\text { Tsuchiya } \\
\text { (2011) }\end{array}$ & UK & $\begin{array}{l}130 \text { respondents from } \\
\text { York, broadly } \\
\text { representative for the } \\
\text { general population in } \\
\text { UK }\end{array}$ & $\begin{array}{c}\text { Social } \\
\text { non-specific } \\
\text { / ex post }\end{array}$ & $\begin{array}{l}\text { choice exercise with } \\
\text { bespoke design; } \\
\text { weights estimated } \\
\text { using the social welfare } \\
\text { function based method }\end{array}$ & $\begin{array}{l}\text { (1) SES: low > high } \\
\text { (2) gender: no effect }\end{array}$ & $\begin{array}{l}\text { SES: a given health gain in life } \\
\text { expectancy to the lowest social } \\
\text { class is weighted (by the median } \\
\text { respondent) about seven to ten } \\
\text { times as highly as an equivalent } \\
\text { gain to the highest social class }\end{array}$ \\
\hline $\begin{array}{l}\text { Dolan and } \\
\text { Tsuchiya } \\
\text { (2012) }\end{array}$ & UK & $\begin{array}{l}600 \text { respondents from } \\
\text { England, broadly } \\
\text { representative of UK } \\
\text { population }\end{array}$ & $\begin{array}{c}\text { Social } \\
\text { non-specific } \\
\text { / ex post }\end{array}$ & $\begin{array}{l}\text { choice exercise with } \\
\text { bespoke design; } \\
\text { weights estimated } \\
\text { using the social welfare } \\
\text { function based method }\end{array}$ & $\begin{array}{l}\text { age and health profile before treatment: } \\
\text { value of health gain is larger for young } \\
\text { people whose QOL is low }\end{array}$ & $\begin{array}{l}\text { Reported in Table } 1 \text { of Dolan and } \\
\text { Tsuchiya (2012), e.g., the general } \\
\text { public value extra } 1 \text { year in full } \\
\text { health for a } 50 \text {-year-old who is } \\
\text { otherwise about to die as about the } \\
\text { same as extra } 10 \text { years in full health } \\
\text { for a } 70 \text {-year-old who is otherwise } \\
\text { about to die. }\end{array}$ \\
\hline $\begin{array}{l}\text { Edlin et al. } \\
\text { (2012) }\end{array}$ & UK & $\begin{array}{l}\text { a sample of } 559 \\
\text { respondents broadly } \\
\text { representative of UK } \\
\text { general population }\end{array}$ & $\begin{array}{c}\text { Social } \\
\text { non-specific } \\
\text { / ex post }\end{array}$ & $\begin{array}{l}\text { choice exercise with } \\
\text { bespoke design }\end{array}$ & $\begin{array}{l}\text { (1) lifetime health: the poorer are favoured } \\
\text { (2) self-induced illness: disfavoured but its } \\
\text { effect may be outweighed by the lifetime } \\
\text { health effect }\end{array}$ & \\
\hline $\begin{array}{l}\text { Eisenberg et } \\
\text { al. (2011) }\end{array}$ & US & $\begin{array}{l}2132 \text { respondents from } \\
\text { a nationally } \\
\text { representative online } \\
\text { panel }\end{array}$ & $\begin{array}{c}\text { Social } \\
\text { non-specific } \\
\text { / ex post }\end{array}$ & PTO & age: the young are favored over the old & $\begin{array}{l}\text { the weights for age } 10 \text { and } 60 \text { are } \\
\text { larger than } 10: 1\end{array}$ \\
\hline
\end{tabular}




\begin{tabular}{|c|c|c|c|c|c|}
\hline $\begin{array}{l}\text { Green } \\
\text { (2009) }\end{array}$ & UK & $\begin{array}{l}261 \text { respondents from } \\
\text { Southampton City } \\
\text { Council, broadly } \\
\text { representative of local } \\
\text { population }\end{array}$ & $\begin{array}{c}\text { Social } \\
\text { non-specific } \\
\text { / ex post }\end{array}$ & $\begin{array}{l}\text { choice exercise with } \\
\text { bespoke design }\end{array}$ & $\begin{array}{l}\text { (1) Severity: In the severity of health } \\
\text { question } 60 \% \text { indicated that a unit of health } \\
\text { gain in a severely affected patient group was } \\
\text { of greater social value to that same unit of } \\
\text { health gain in a moderately affected patient } \\
\text { group, all else equal. } \\
\text { (2) SES: When described by level of } \\
\text { disadvantage, } 80 \% \text { of respondents stated } \\
\text { such a preference, which indicates that they } \\
\text { attach a greater social value to a unit of } \\
\text { health gain in a disadvantaged patient group, } \\
\text { compared to a more advantaged group, all } \\
\text { else equal. }\end{array}$ \\
\hline $\begin{array}{l}\text { Green and } \\
\text { Gerard } \\
\text { (2009) }\end{array}$ & UK & $\begin{array}{l}259 \text { respondents from } \\
\text { Southampton City } \\
\text { Council }\end{array}$ & $\begin{array}{l}\text { Impartial } \\
\text { decision } \\
\text { maker / ex } \\
\text { ante }\end{array}$ & DCE & $\begin{array}{l}\text { (1) the average health improvement } \\
\text { expected from the treatment: large > } \\
\text { moderate > small> very small } \\
\text { (2) cost-effectiveness of treatment - the } \\
\text { value for money expected from the } \\
\text { treatment: very good > fairly good > fairly } \\
\text { poor > very poor } \\
\text { (3) severity: yes > no } \\
\text { (4) availability of other treatments: yes > no }\end{array}$ \\
\hline
\end{tabular}




\begin{tabular}{|c|c|c|c|c|c|}
\hline $\begin{array}{l}\text { Gyrd-Hanse } \\
\text { n (2004) }\end{array}$ & Demark & $\begin{array}{l}\text { a random sample of } \\
3201 \text { respondents from } \\
\text { Denmark }\end{array}$ & $\begin{array}{c}\text { Social } \\
\text { non-specific } \\
\text { / ex post }\end{array}$ & DCE & $\begin{array}{l}\text { QOL(measured using EQ-5D health states) } \\
\text { before and after treatment: patients in a more } \\
\text { severe health state are favoured provided } \\
\text { their expected benefits are large enough to } \\
\text { bring them to the health level where their } \\
\text { rival patients are without treatment - this } \\
\text { equity concern was more significant on } \\
\text { specific health dimensions such as } \\
\text { pain/discomfort and anxiety/depression. }\end{array}$ \\
\hline $\begin{array}{l}\text { Gyrd-Hanse } \\
\mathrm{n} \text { and } \\
\text { Kristiansen } \\
\text { (2008) }\end{array}$ & $\begin{array}{l}\text { The } \\
\text { Netherlands }\end{array}$ & $\begin{array}{l}\text { a random sample of } \\
2900 \text { respondents from } \\
\text { Denmark }\end{array}$ & $\begin{array}{l}\text { Social } \\
\text { non-specific } \\
\text { / ex ante }\end{array}$ & DCE & $\begin{array}{l}\text { Distribution of fixed gain: In the context of } \\
\text { life-saving, it shows there are preferences } \\
\text { for both spreading and concentration of } \\
\text { health gains. Respondents also adopt } \\
\text { thresholds when they value treatment offers } \\
\text { (spreading is preferred if size of gain }>6 \\
\text { months life expectancy or probability of } \\
\text { gains }>1 / 12 \text { ). This result is consistent } \\
\text { regardless of the perspectives. }\end{array}$ \\
\hline
\end{tabular}




\begin{tabular}{|c|c|c|c|c|c|c|}
\hline $\begin{array}{l}\text { Jelsma et al. } \\
\text { (2002) }\end{array}$ & Zimbabwe & $\begin{array}{l}\text { a random sample of } 67 \\
\text { respondents from a } \\
\text { high-density area of } \\
\text { Harare }\end{array}$ & $\begin{array}{c}\text { Social } \\
\text { non-specific } \\
\text { / ex post }\end{array}$ & PTO & $\begin{array}{l}\text { age: the young are favored over the old, and } \\
15 \text { is the most highly valued age }\end{array}$ & $\begin{array}{l}\text { The mean weights for } 1,15,30,45 \text {, } \\
\text { and } 75 \text { years are } \\
\text { (1) } 1.76,2.19,1,0.76 \text {, and } 0.33 \\
\text { (when gain is stated as lifesaving) } \\
\text { (2) } 0.95,1.67,1,0.97 \text {, and } 0.43 \\
\text { (when gain is stated as sparing one } \\
\text { year of illness) }\end{array}$ \\
\hline $\begin{array}{l}\text { Johannesson } \\
\text { and } \\
\text { Johansson } \\
\text { (1996) }\end{array}$ & Sweden & $\begin{array}{l}\text { a random sample of } \\
1000 \text { respondents from } \\
\text { Sweden }\end{array}$ & $\begin{array}{c}\text { Social } \\
\text { non-specific } \\
\text { / ex post }\end{array}$ & PTO & age: the young are favored over the old & $\begin{array}{l}\text { The weights for life saving at } 30,50 \\
\text { and } 70 \text { years old are } 1.0,0.2 \text {, and } \\
0.029 \text {. }\end{array}$ \\
\hline $\begin{array}{l}\text { Johannesson } \\
\text { and } \\
\text { Johansson } \\
\text { (1997) }\end{array}$ & Sweden & $\begin{array}{l}\text { a random sample of } \\
1000 \text { respondents from } \\
\text { Sweden }\end{array}$ & $\begin{array}{c}\text { Social } \\
\text { non-specific } \\
\text { / ex post }\end{array}$ & PTO & age: the young are favored over the old & $\begin{array}{l}\text { Using parametric estimation, the } \\
\text { weights for life saving at } 30,50 \text { and } \\
70 \text { years old are } 1,0.13 \text {, and } 0.025 \text {. } \\
\text { Using nonparametric estimation, } \\
\text { the weights for life saving at } 30,50 \\
\text { and } 70 \text { years old are } 1.0,0.2 \text {, and } \\
0.029 \text {. }\end{array}$ \\
\hline $\begin{array}{l}\text { Johri et al. } \\
\text { (2009) }\end{array}$ & US/Canada & $\begin{array}{l}\text { a sample of } 2009 \\
\text { respondents from an } \\
\text { online panel broadly } \\
\text { representative of US } \\
\text { and Canada }\end{array}$ & $\begin{array}{l}\text { Impartial } \\
\text { decision } \\
\text { maker / ex } \\
\text { ante }\end{array}$ & $\begin{array}{l}\text { simple choice exercise: } \\
\text { allocation of points }\end{array}$ & $\begin{array}{l}\text { age: people generally prefer allocating } \\
\text { scarce resources to young patients over older } \\
\text { ones but these preferences are significantly } \\
\text { reduced when participants are encouraged to } \\
\text { reflect carefully on a wide range of moral } \\
\text { principles }\end{array}$ & \\
\hline
\end{tabular}




\begin{tabular}{|c|c|c|c|c|c|c|}
\hline $\begin{array}{l}\text { Lim et al. } \\
\text { (2012) }\end{array}$ & South Korea & $\begin{array}{l}716 \text { respondents from } \\
\text { an internet panel } \\
\text { broadly representative } \\
\text { of Korea population }\end{array}$ & Not reported & DCE & $\begin{array}{l}\text { (1) QOL without treatment: low > high } \\
\text { (2) life years remaining without treatment: } \\
\text { short > long } \\
\text { (3) survival gain after treatment: large > } \\
\text { small } \\
\text { (4) QOL gain after treatment: high > low } \\
\text { (5) patient's household income level: low > } \\
\text { high }\end{array}$ & \\
\hline $\begin{array}{l}\text { Lancsar et } \\
\text { al. (2011) }\end{array}$ & UK & $\begin{array}{l}\text { a random sample of } \\
587 \text { from the adult } \\
\text { population in England }\end{array}$ & $\begin{array}{c}\text { Social } \\
\text { non-specific } \\
\text { / ex post }\end{array}$ & $\begin{array}{l}\text { DCE; weights } \\
\text { calculated using a } \\
\text { compensating variation } \\
\text { based method }\end{array}$ & $\begin{array}{l}\text { (1) age at onset: insignificant } \\
\text { (2) age at death if untreated: significant } \\
\text { (log-transformed, polynomial) } \\
\text { (3) QOL if untreated: insignificant (QOL } \\
\text { loss, log-transformed, polynomial), less } \\
\text { severe is favoured } \\
\text { (4) gain in life expectancy } \\
\text { (5) gain in QOL with treatment } \\
\text { The last two are combined as QALY gain, } \\
\text { and participants preferred to treat patients } \\
\text { who had larger QALY gains, but at a } \\
\text { diminishing rate. } \\
\text { end of life (implied): not favored }\end{array}$ & $\begin{array}{l}\text { Weights for individual attribute } \\
\text { levels (details in Table } 4 \text { of Lancsar } \\
\text { et al. (2011)): } \\
\text { Age of death without treatment: } \\
\text { weights for } 1,10,20,40,60,70 \text {, and } \\
80 \text { years old are } \\
\text { 1.08,1.16,1.03,1,1.03, and } 1.06 \text {; } \\
\text { QOL loss: weights for } 0.8,0.9,0.7 \text {, } \\
0.4 \text {, and } 0.1 \text { QOL loss are } 0.98 \text {, } \\
0.96,1,1.04 \text {, and } 1.03 \\
\text { Weights for combination of } \\
\text { multiple attributes (see Table } 5 \text { of } \\
\text { Lancsar et al. (2011)) }\end{array}$ \\
\hline
\end{tabular}




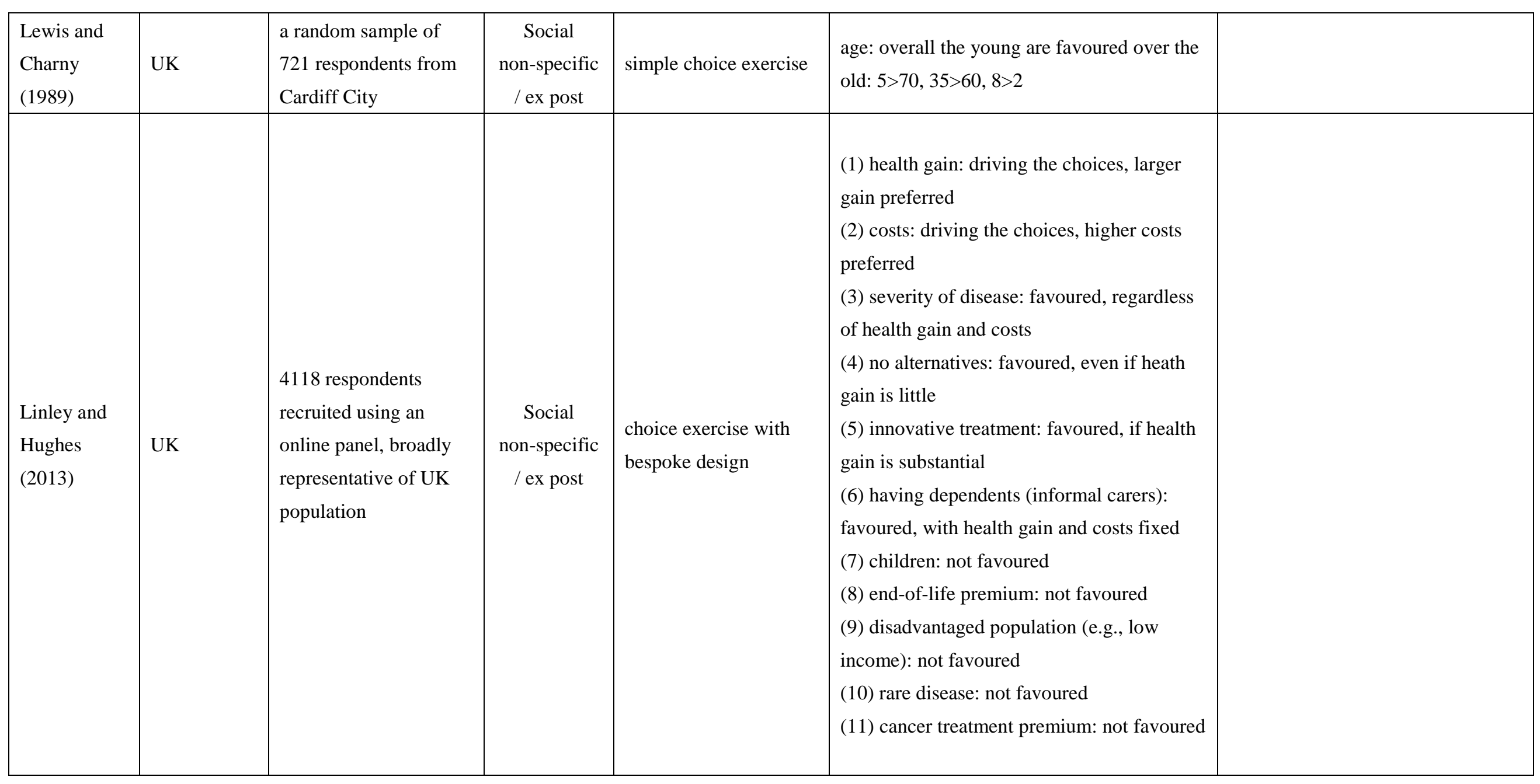




\begin{tabular}{|c|c|c|c|c|c|c|}
\hline $\begin{array}{l}\text { Mortimer } \\
\text { and Segal } \\
\text { (2008) }\end{array}$ & Australia & $\begin{array}{l}\text { a random sample of } \\
271 \text { from Australia }\end{array}$ & $\begin{array}{c}\text { Social } \\
\text { non-specific } \\
\text { / unclear }\end{array}$ & DCE & $\begin{array}{l}\text { (1) self-induced illness: no>yes } \\
\text { (2) purpose of the intervention: } \\
\text { prevention>cure } \\
\text { (3) type of intervention: medical, lifestyle } \\
\text { (4) number of lives saved per year: the more } \\
\text { the better (the more effective one is } \\
\text { favoured) } \\
\text { (5) quality of evidence: strong>limited } \\
\text { (6) cost of treatment: less costly is favoured } \\
\text { (7) contributions from patients: less } \\
\text { out-of-pocket contribution is favoured } \\
\text { (8) age/life-stage: young children > young } \\
\text { adult > working-age adult > older-age retiree }\end{array}$ & \\
\hline $\begin{array}{l}\text { Nord et al. } \\
\text { (1993) }\end{array}$ & Norway & $\begin{array}{l}\text { a random sample of } \\
102 \text { respondents from } \\
\text { Norway }\end{array}$ & $\begin{array}{l}\text { Impartial } \\
\text { decision } \\
\text { maker / ex } \\
\text { ante }\end{array}$ & PTO & $\begin{array}{l}\text { severity: more severe health state is valued } \\
\text { higher }\end{array}$ & $\begin{array}{l}\text { reported in Table } 5 \text { of Nord et al. } \\
\text { (1993), e.g., saving one life is } \\
\text { equivalent to returning } 3 \text { patients at } \\
\text { the health state (112232) to full } \\
\text { health }\end{array}$ \\
\hline $\begin{array}{l}\text { Nord et al. } \\
\text { (1995) }\end{array}$ & Australia & $\begin{array}{l}119 \text { respondents from } \\
\text { Melbourne }\end{array}$ & $\begin{array}{c}\text { Social } \\
\text { non-specific } \\
\text { / ex post }\end{array}$ & $\begin{array}{l}\text { simple choice exercise: } \\
\text { allocation of fixed } \\
\text { budget }\end{array}$ & $\begin{array}{l}\text { cost of treatment: not significant in } \\
\text { determining priorities }\end{array}$ & \\
\hline
\end{tabular}




\begin{tabular}{|c|c|c|c|c|c|c|}
\hline $\begin{array}{l}\text { Nord et al. } \\
\text { (1996) }\end{array}$ & Australia & $\begin{array}{l}176 \text { respondents from } \\
\text { Melbourne and four } \\
\text { country towns }\end{array}$ & $\begin{array}{l}\text { Impartial } \\
\text { decision } \\
\text { maker / ex } \\
\text { post }\end{array}$ & PTO & $\begin{array}{l}\text { (1) age: the young are favored over the old } \\
\text { (2) size of health gain: the larger gain is } \\
\text { favored but at a diminishing rate }\end{array}$ & $\begin{array}{l}\text { Age weights are similar in two } \\
\text { health gain scenarios: for } 10,20,60 \\
\text { and } 80 \text { years, the median weights } \\
\text { are } 1.1,1.0,0.4 \text { and } 0.1 \text {. } \\
\text { The discounted rates for health gain } \\
\text { are calculated for different contexts } \\
\text { and perspectives. }\end{array}$ \\
\hline $\begin{array}{l}\text { Norman et } \\
\text { al. (2013) }\end{array}$ & Australia & $\begin{array}{l}552 \text { respondents } \\
\text { recruited from an } \\
\text { online panel broadly } \\
\text { representative of the } \\
\text { Australia population }\end{array}$ & $\begin{array}{c}\text { Social } \\
\text { non-specific } \\
\text { / ex post }\end{array}$ & $\begin{array}{l}\text { DCE, weights } \\
\text { calculated using the } \\
\text { marginal rate of } \\
\text { substitution }\end{array}$ & $\begin{array}{l}\text { (1) gender: insignificant } \\
\text { (2) smoking status: no>yes } \\
\text { (3) income/SES: low income > high income } \\
\text { (4) lifestyle: healthy > not healthy } \\
\text { (5) carer status: carer > non carer } \\
\text { (6) age of death/remaining LE if untreated: } \\
\text { 45>60>75 } \\
\text { (7) extra LE if treated (health gain): the } \\
\text { larger the better but a diminishing effect }\end{array}$ & $\begin{array}{l}\text { Weights for combination of } \\
\text { attributes reported in Table } 3 \text { and } 4 \\
\text { of Norman et al. (2013) }\end{array}$ \\
\hline Olsen (2000) & Norway & $\begin{array}{l}716 \text { respondents from } \\
\text { the adult population in } \\
\text { Norway }\end{array}$ & $\begin{array}{l}\text { Citizen / ex } \\
\text { post }\end{array}$ & $\begin{array}{l}\text { choice exercise with } \\
\text { bespoke design }\end{array}$ & $\begin{array}{l}\text { Distribution of fixed gain: there is a } \\
\text { threshold level of benefits to the larger } \\
\text { group above which people prefer to } \\
\text { distribute gains to as many people as } \\
\text { possible but below which they prefer to } \\
\text { concentrate gains. }\end{array}$ & \\
\hline
\end{tabular}




\begin{tabular}{|c|c|c|c|c|c|c|}
\hline Olsen (2013) & Norway & $\begin{array}{l}\text { a sample of } 503 \\
\text { respondents broadly } \\
\text { representative of } \\
\text { Norway general } \\
\text { population }\end{array}$ & $\begin{array}{c}\text { Social } \\
\text { non-specific } \\
\text { / ex post }\end{array}$ & $\begin{array}{l}\text { choice exercise with } \\
\text { bespoke design }\end{array}$ & $\begin{array}{l}\text { (1) age: the young are favoured } \\
\text { (2) size of gain: large gain is favoured } \\
\text { (3) end of life: little support for the } \\
\text { "end-of-life" argument that a short life } \\
\text { expectancy makes patients entitled to } \\
\text { preferential treatment. }\end{array}$ & \\
\hline $\begin{array}{l}\text { Olsen and } \\
\text { Donaldson } \\
\text { (1998) }\end{array}$ & Norway & $\begin{array}{l}\text { a representative sample } \\
\text { of } 143 \text { from Troms } \\
\text { county }\end{array}$ & $\begin{array}{l}\text { Citizen / ex } \\
\text { ante }\end{array}$ & CVM & $\begin{array}{l}\text { type of health gains: life saving QALY } \\
\text { gain > life extending QALY > QOL } \\
\text { improving QALY (WTP/QALY: } 2 \text { NOK, } \\
1.5 \text { NOK, } 0.2 \text { NOK) }\end{array}$ & \\
\hline $\begin{array}{l}\text { Palanca-Tan } \\
\text { (2013) }\end{array}$ & Philippines & $\begin{array}{l}\text { a quota sample of } 500 \\
\text { respondents from the } \\
\text { five largest cities in } \\
\text { Metro Manila }\end{array}$ & $\begin{array}{c}\text { Social } \\
\text { non-specific } \\
\text { / ex post }\end{array}$ & $\begin{array}{l}\text { DCE, weights } \\
\text { estimated using the } \\
\text { social welfare function } \\
\text { based method }\end{array}$ & $\begin{array}{l}\text { (1) age: } 1-19>\text { below } 1>20-59>60+ \\
\text { (2) number of patients: significant positive } \\
\text { effect } \\
\text { (3) life-years saved: significant positive } \\
\text { effect }\end{array}$ & $\begin{array}{l}\text { Based on model 1, the weights for } \\
\text { life saving among age groups } \\
\text { 'below 1', '1-19', '20-59', and ' } 60+\text { ' } \\
\text { are } 4,5,3 \text {, and } 1 \text {. }\end{array}$ \\
\hline $\begin{array}{l}\text { Pennington } \\
\text { et al. (2013) }\end{array}$ & $\begin{array}{l}\text { Denmark, } \\
\text { France, } \\
\text { Hungary, } \\
\text { Netherlands, } \\
\text { Norway, } \\
\text { Poland, } \\
\text { Spain, } \\
\text { Sweden, UK }\end{array}$ & $\begin{array}{l}17657 \text { respondents } \\
\text { across nine European } \\
\text { countries }\end{array}$ & $\begin{array}{l}\text { Personal / ex } \\
\text { post }\end{array}$ & CVM & $\begin{array}{l}\text { (1) type of gains: value for life extending } \\
\text { gains > value for QOL enhancing gains } \\
\text { (2)end of life: modest premium indicated for } \\
\text { end of life treatment }\end{array}$ & \\
\hline
\end{tabular}




\begin{tabular}{|c|c|c|c|c|c|c|}
\hline $\begin{array}{l}\text { Petrou et al. } \\
\text { (2013) }\end{array}$ & UK & $\begin{array}{l}2500 \text { respondents from } \\
\text { an internet panel in UK }\end{array}$ & $\begin{array}{l}\text { Impartial } \\
\text { decision } \\
\text { maker / ex } \\
\text { post }\end{array}$ & PTO & $\begin{array}{l}\text { age: the young are favored over the old, and } \\
30 \text { is the most highly valued age }\end{array}$ & $\begin{array}{l}\text { Estimated weights vary according } \\
\text { to different framings, age bases, } \\
\text { and methods. In most cases, } \\
\text { 30-year-olds have the highest mean } \\
\text { weight. }\end{array}$ \\
\hline $\begin{array}{l}\text { Pinto-Prades } \\
\text { et al. (2014) }\end{array}$ & Spain & $\begin{array}{l}813 \text { respondents } \\
\text { broadly representative } \\
\text { of the Spain adult } \\
\text { general population }\end{array}$ & $\begin{array}{l}\text { CVM: } \\
\text { Personal / ex } \\
\text { post } \\
\text { PTO: } \\
\text { impartial } \\
\text { decision } \\
\text { maker / ex } \\
\text { post }\end{array}$ & CVM and PTO & $\begin{array}{l}\text { (1) end of life premium: yes } \\
\text { (2) type of gain: at the end of life, quality of } \\
\text { life improvement > life extension }\end{array}$ & $\begin{array}{l}\text { The weights for end of life } \\
\text { treatment and temporary health gain } \\
\text { are around } 1.5 \text { to } 1 \text {. The weights for } \\
\text { QOL improvement at the end of life } \\
\text { and life extension at the end of life } \\
\text { are around } 1.5 \text { to } 1 .\end{array}$ \\
\hline $\begin{array}{l}\text { Quintal } \\
\text { (2009) }\end{array}$ & Portugal & $\begin{array}{l}70 \text { respondents from } \\
\text { two Portuguese } \\
\text { municipalities }\end{array}$ & $\begin{array}{l}\text { Impartial } \\
\text { decision } \\
\text { maker / ex } \\
\text { post }\end{array}$ & PTO & $\begin{array}{l}\text { geographical equality of health gain } \\
\text { distribution: preferred but not at any cost }\end{array}$ & $\begin{array}{l}\text { In the context of preventing } \\
\text { children from diseases, the median } \\
\text { respondent in both samples gives a } \\
\text { weight of } 0.8 \text { to } 1 \text { for a health gain } \\
\text { concentrated in region } 1 \text { and a } \\
\text { health gain equally divided between } \\
\text { the two regions. }\end{array}$ \\
\hline
\end{tabular}




\begin{tabular}{|c|c|c|c|c|c|c|}
\hline $\begin{array}{l}\text { Richardson } \\
\text { et al. (2011) }\end{array}$ & Australia & $\begin{array}{l}\text { a sample of } 430 \\
\text { respondents broadly } \\
\text { representative of } \\
\text { Australian general } \\
\text { population }\end{array}$ & $\begin{array}{c}\text { Social } \\
\text { non-specific } \\
\text { / ex post }\end{array}$ & $\begin{array}{l}\text { PTO, weights } \\
\text { calculated as a function } \\
\text { of TTO utility scores } \\
\text { and severity measure } \\
\text { (QOL loss) }\end{array}$ & $\begin{array}{l}\text { (1) severity of pre-treatment condition: } \\
\text { highly significant } \\
\text { (2) size of health gain: positive but } \\
\text { diminishing }\end{array}$ & $\begin{array}{l}\text { See Table } 7 \text { of Richardson et al. } \\
\text { (2011) }\end{array}$ \\
\hline $\begin{array}{l}\text { Richardson } \\
\text { et al. (2012) }\end{array}$ & Australia & $\begin{array}{l}\text { a sample of } 532 \\
\text { respondents } \\
\text { representative of } \\
\text { Australia general } \\
\text { population }\end{array}$ & $\begin{array}{l}\text { Impartial } \\
\text { decision } \\
\text { maker / ex } \\
\text { post }\end{array}$ & $\begin{array}{l}\text { choice exercise with } \\
\text { bespoke design }\end{array}$ & $\begin{array}{l}\text { distribution of fixed gain: very strong } \\
\text { preference for 'dispersion' of benefits rather } \\
\text { than their 'concentration' }\end{array}$ & \\
\hline $\begin{array}{l}\text { Roberts et al. } \\
\text { (1999) }\end{array}$ & UK & $\begin{array}{l}\text { a random sample of } 91 \\
\text { respondents, broadly } \\
\text { representative of the } \\
\text { population of a health } \\
\text { district in south-east } \\
\text { England }\end{array}$ & $\begin{array}{c}\text { Social } \\
\text { non-specific } \\
\text { / ex post }\end{array}$ & DCE & $\begin{array}{l}\text { (1) the chance of success of the intervention: } \\
0.1 \%, 1 \%, 10 \%, 50 \% \\
\text { (2) the number of people receiving } \\
\text { treatments: } 1,10,100 \\
\text { (3) survival gains if treatment is successful: } \\
1 \text { year, } 5 \text { years } \\
\text { (4) health state after treatment: good > poor } \\
\text { (little support for health care programs that } \\
\text { left patients in relatively poor health states } \\
\text { even though this represented a prognostic } \\
\text { improvement) }\end{array}$ & \\
\hline
\end{tabular}




\begin{tabular}{|c|c|c|c|c|c|c|}
\hline & & & & & $\begin{array}{l}\text { Results for the first three attributes were not } \\
\text { reported. }\end{array}$ & \\
\hline $\begin{array}{l}\text { Ryynanen et } \\
\text { al. (1996) }\end{array}$ & Finland & $\begin{array}{l}\text { a random sample of } 49 \\
\text { respondents recruited } \\
\text { using a telephone } \\
\text { directory }\end{array}$ & $\begin{array}{c}\text { Social } \\
\text { non-specific } \\
\text { / ex post }\end{array}$ & $\begin{array}{l}\text { DCE (called random } \\
\text { paired scenarios in the } \\
\text { paper) }\end{array}$ & $\begin{array}{l}\text { (1) age: child >old } \\
\text { (2) severity of disease: severe > mild } \\
\text { (3) prognosis: poor > good } \\
\text { (4) cost of treatment: expensive > } \\
\text { inexpensive } \\
\text { (5) self-induced: no > yes }\end{array}$ & \\
\hline $\begin{array}{l}\text { Schwappach } \\
(2002)\end{array}$ & Germany & $\begin{array}{l}\text { a sample of } 127 \\
\text { respondents from an } \\
\text { online survey in } \\
\text { Germany }\end{array}$ & $\begin{array}{l}\text { Impartial } \\
\text { decision } \\
\text { maker / ex } \\
\text { post }\end{array}$ & PTO & $\begin{array}{l}\text { improving patients' health > avoiding } \\
\text { decline (cure > prevention) }\end{array}$ & $\begin{array}{l}\text { The mean substitution rate between } \\
\text { health improvements and avoided } \\
\text { decline ranged between } 0.47 \text { and } \\
0.64 \text { dependent on the intervention. } \\
\text { See more details in Table } 3 \text { of } \\
\text { Schwappach (2002). }\end{array}$ \\
\hline $\begin{array}{l}\text { Schwappach } \\
\text { and } \\
\text { Strasmann } \\
\text { (2006) }\end{array}$ & Germany & $\begin{array}{l}\text { a random sample from } \\
\text { an internet panel; } 843 \\
\text { completed the first } \\
\text { survey; among them } \\
716 \text { completed the } \\
\text { second one }\end{array}$ & $\begin{array}{l}\text { Impartial } \\
\text { decision } \\
\text { maker / ex } \\
\text { ante }\end{array}$ & $\begin{array}{l}\text { choice experiments } \\
\text { with allocation of } \\
\text { points }\end{array}$ & $\begin{array}{l}\text { (1) age: children > employable age > } \\
\text { teenager > seniors } \\
\text { (2) combination of initial and post-treatment } \\
\text { QOL: low-high > moderate-high > } \\
\text { low-low > high-high } \\
\text { (3) effect on life expectancy: plus } 10 \text { years > }\end{array}$ & \\
\hline
\end{tabular}




\begin{tabular}{|c|c|c|c|c|c|c|}
\hline & & & & & $\begin{array}{l}\text { plus } 5 \text { years }>\text { no effect }>\text { minus } 5 \text { years } \\
\text { (4) frequency of the disease: common }>\text { rare } \\
\text { (5) costs: below average }>\text { above average }\end{array}$ & \\
\hline $\begin{array}{l}\text { Shah et al. } \\
\text { (2013) }\end{array}$ & UK & $\begin{array}{l}\text { a quota sample of } 50 \\
\text { respondents broadly } \\
\text { representative of the } \\
\text { UK general population }\end{array}$ & $\begin{array}{l}\text { Social } \\
\text { non-specific } \\
\text { / ex post }\end{array}$ & $\begin{array}{l}\text { choice exercise with } \\
\text { bespoke design }\end{array}$ & $\begin{array}{l}\text { end of life: weak evidence of support for } \\
\text { giving priority to the patient with shorter } \\
\text { remaining life expectancy } \\
\text { At end of life, QOL improvement > life } \\
\text { extension }\end{array}$ & \\
\hline $\begin{array}{l}\text { Shiroiwa et } \\
\text { al. (2013) }\end{array}$ & Japan & $\begin{array}{l}\text { a random sample of } \\
2283 \text { respondents from } \\
\text { an online panel, } \\
\text { broadly representative } \\
\text { of Japanese general } \\
\text { population }\end{array}$ & $\begin{array}{l}\text { Personal / ex } \\
\text { post }\end{array}$ & CVM & $\begin{array}{l}\text { (1) severity: more severe health state is } \\
\text { valued higher } \\
\text { (2) end of life premium: no }\end{array}$ & \\
\hline $\begin{array}{l}\text { Singh et al. } \\
\text { (2012) }\end{array}$ & UK & $\begin{array}{l}\text { a sample of } 1030 \\
\text { respondents } \\
\text { representative of UK } \\
\text { general population } \\
\end{array}$ & $\begin{array}{l}\text { Social } \\
\text { non-specific } \\
\text { / ex post }\end{array}$ & PTO & $\begin{array}{l}\text { self-induced/unhealthy lifestyle: less weight } \\
\text { was given to interventions related to } \\
\text { self-induced illness than that is caused by } \\
\text { health care or nature (genetic disorders) }\end{array}$ & $\begin{array}{l}\text { The weights for genetic disorder, } \\
\text { lifestyle disease, and sport injury } \\
\text { are } 1,0.65 \text {, and } 0.41 \text {. }\end{array}$ \\
\hline $\begin{array}{l}\text { Tsuchiya } \\
\text { and Dolan } \\
\text { (2007) }\end{array}$ & UK & $\begin{array}{l}271 \text { members of the } \\
\text { UK public }\end{array}$ & $\begin{array}{l}\text { Social } \\
\text { non-specific } \\
\text { / ex post }\end{array}$ & $\begin{array}{l}\text { choice exercise: } \\
\text { bespoke design }\end{array}$ & $\begin{array}{l}\text { social class: low > high (much stronger } \\
\text { preference then the clinician sample) }\end{array}$ & \\
\hline
\end{tabular}




\begin{tabular}{|c|c|c|c|c|c|}
\hline $\begin{array}{l}\text { Tsuchiya et } \\
\text { al. (2003) }\end{array}$ & UK & $\begin{array}{l}140 \text { respondents from } \\
\text { Yorks and Humberside } \\
\text { (not representative on } \\
\text { some variables) }\end{array}$ & $\begin{array}{c}\text { Social } \\
\text { non-specific } \\
\text { / ex post }\end{array}$ & simple ranking exercise & $\begin{array}{l}\text { age: overall the young are favored over the } \\
\text { old }\end{array}$ \\
\hline Ubel (1999) & US & $\begin{array}{l}479 \text { prospective jurors } \\
\text { in Philadelphia }\end{array}$ & $\begin{array}{l}\text { Q1,2,4,5: } \\
\text { Social } \\
\text { non-specific } \\
\text { / ex post } \\
\text { Q4,6: citizen } \\
\text { / ex ante }\end{array}$ & simple choice exercise & $\begin{array}{l}\text { severity of illness: more severe is favoured } \\
\text { but affected by framing effects }\end{array}$ \\
\hline $\begin{array}{l}\text { Ubel et al. } \\
\text { (1996) }\end{array}$ & US & $\begin{array}{l}568 \text { prospective jurors } \\
\text { in Philadelphia }\end{array}$ & $\begin{array}{c}\text { Social } \\
\text { non-specific } \\
\text { / ex post }\end{array}$ & simple choice exercise & $\begin{array}{l}\text { distribution of fixed gain: a small gain to the } \\
\text { many> a large gain to the few (strong } \\
\text { preference for giving more a benefit) }\end{array}$ \\
\hline $\begin{array}{l}\text { Ubel et al. } \\
\text { (1998) }\end{array}$ & US & $\begin{array}{l}228 \text { prospective jurors } \\
\text { at the Philadelphia } \\
\text { County courthouse }\end{array}$ & $\begin{array}{c}\text { Social } \\
\text { non-specific } \\
\text { / ex post }\end{array}$ & $\begin{array}{l}\text { choice exercise with } \\
\text { bespoke design }\end{array}$ & $\begin{array}{l}\text { (1) severity: significant preference for } \\
\text { directing limited resources toward those } \\
\text { with greater disabilities, regardless of } \\
\text { whether those resources were targeted } \\
\text { toward prevention or cure. } \\
\text { (2) prevention vs cure: when the magnitude } \\
\text { of benefit was held constant, the subjects } \\
\text { slightly preferred prevention over cure. }\end{array}$ \\
\hline
\end{tabular}




\begin{tabular}{|c|c|c|c|c|c|c|}
\hline $\begin{array}{l}\text { Ubel et al. } \\
\text { (1999) }\end{array}$ & US & $\begin{array}{l}251 \text { prospective jurors } \\
\text { in Philadelphia ( not } \\
\text { representative but } \\
\text { some variations in } \\
\text { backgrounds) }\end{array}$ & $\begin{array}{l}\text { Impartial } \\
\text { decision } \\
\text { maker / ex } \\
\text { post }\end{array}$ & PTO & $\begin{array}{l}\text { treatment potential: lifesaving to perfect } \\
\text { health has the same value as lifesaving to } \\
\text { pre-existing paraplegia but much larger } \\
\text { value than lifesaving to onset paraplegia } \\
\text { (treatment causes paraplegia) and lifesaving } \\
\text { to avoidable paraplegia (treatment causes } \\
\text { paraplegia which is avoidable) }\end{array}$ & $\begin{array}{l}\text { lifesaving to perfect health vs } \\
\text { lifesaving to pre-existing paraplegia } \\
\text { vs lifesaving to onset paraplegia } \\
\text { (treatment causes paraplegia) vs } \\
\text { lifesaving to avoidable paraplegia } \\
\text { (treatment causes paraplegia which } \\
\text { is avoidable) = 1:1:50:5000 }\end{array}$ \\
\hline $\begin{array}{l}\text { Ubel et al. } \\
\text { (2000) }\end{array}$ & US & $\begin{array}{l}495 \text { prospective jurors } \\
\text { in Philadelphia }\end{array}$ & $\begin{array}{l}\text { Social } \\
\text { non-specific } \\
\text { / ex post }\end{array}$ & simple choice exercise & $\begin{array}{l}\text { distribution of fixed gain: preference for } \\
\text { giving more people gain is affected by } \\
\text { framing effects }\end{array}$ & \\
\hline $\begin{array}{l}\text { Ubel et al. } \\
\text { (2001) }\end{array}$ & US & $\begin{array}{l}\text { study1: } 615 \\
\text { prospective jurors in } \\
\text { Philadelphia; study 2: a } \\
\text { sample of } 68 \\
\text { respondents from the } \\
\text { internet }\end{array}$ & $\begin{array}{c}\text { Social } \\
\text { non-specific } \\
\text { / ex post }\end{array}$ & simple choice exercise & $\begin{array}{l}\text { distribution of fixed gain: preference for } \\
\text { giving more people gain is affected by } \\
\text { framing effects and order effects }\end{array}$ & \\
\hline
\end{tabular}




\begin{tabular}{|c|c|c|c|c|c|}
\hline $\begin{array}{l}\text { Whitty et al. } \\
\text { (2008) }\end{array}$ & Australia & $\begin{array}{l}\text { a quasi-random sample } \\
\text { of } 161 \text { respondents } \\
\text { from Australia }\end{array}$ & $\begin{array}{c}\text { Social } \\
\text { non-specific } \\
\text { / ex post }\end{array}$ & DCE & $\begin{array}{l}\text { (1) chance of success: significantly positive } \\
\text { (2) average survival, for those in whom the } \\
\text { new pharmaceutical is successful: } \\
\text { significantly positive } \\
\text { (3) average health-related QOL, for those in } \\
\text { whom the new pharmaceutical is successful. } \\
\text { If successfully treated, the recipient remains } \\
\text { in this health state for the duration of their } \\
\text { survival: No pain/discomfort > Moderate } \\
\text { pain/discomfort > Extreme pain/discomfort } \\
\text { (4) additional cost: significantly negative }\end{array}$ \\
\hline $\begin{array}{l}\text { Whitty et al. } \\
\text { (2011) }\end{array}$ & Australia & $\begin{array}{l}\text { a quasi-random sample } \\
\text { of } 161 \text { respondents }\end{array}$ & $\begin{array}{c}\text { Social } \\
\text { non-specific } \\
\text { / ex post }\end{array}$ & DCE & $\begin{array}{l}\text { (1) expected survival if untreated: short (3 } \\
\text { months) > long (15 years) } \\
\text { (2) expected health state if untreated: poor } \\
\text { (extreme pain/discomfort) > moderate } \\
\text { (moderate pain/discomfort and moderate } \\
\text { anxiety/depression) } \\
\text { (3) success rate: } 60 \% \text { < } 90 \% \\
\text { (4) survival gain if treated: significantly } \\
\text { positive } \\
\text { (5) QOL if treated: significantly positive } \\
\text { (6) cost: significantly negative } \\
\text { (7) uncertainty (for decision makers only): }\end{array}$ \\
\hline
\end{tabular}




\begin{tabular}{|c|c|c|c|c|c|}
\hline & & & & & high $<$ low \\
\hline $\begin{array}{l}\text { Whitty et al. } \\
\text { (2014) }\end{array}$ & Australia & $\begin{array}{l}930 \text { respondents from } \\
\text { an online panel } \\
\text { (broadly representative } \\
\text { of Queensland and } \\
\text { Australia population } \\
\text { except on some } \\
\text { variables) }\end{array}$ & $\begin{array}{l}\text { DCE: Social } \\
\text { non-specific } \\
\text { / ex ante } \\
\text { DCE } \\
\text { (BWS): } \\
\text { Social } \\
\text { non-specific } \\
\text { / ex ante }\end{array}$ & DCE, BWS & $\begin{array}{l}\text { DCE: } \\
\text { (1) benefit type: early diagnosis > } \\
\text { prevention > survival improve > hospital } \\
\text { waiting time reduction > QOL } \\
\text { improvement > side effect reduction } \\
\text { (2) good value for money: yes > no } \\
\text { (3) alternative treatment available: no } \\
\text { alternatives > upgrade of an existing } \\
\text { intervention > an alternative but different } \\
\text { intervention is already available } \\
\text { (4) number of patients: } \\
\text { 1000>=2000>500>10 } \\
\text { (5) age: } 35>10>60>85 \\
\text { (6) indigenous Queenslanders: yes > no } \\
\text { (7) rural or remote area: yes > no } \\
\text { BWS: } \\
\text { reversal of preference ordering for some }\end{array}$ \\
\hline
\end{tabular}




\begin{tabular}{|c|c|c|c|c|c|}
\hline & & & & & attributes (benefit type and age) \\
\hline $\begin{array}{l}\text { Winkelhage } \\
\text { and } \\
\text { Diederich } \\
\text { (2007) }\end{array}$ & Germany & $\begin{array}{l}120 \text { respondents from } \\
\text { Bremen, broadly } \\
\text { representative of local } \\
\text { population }\end{array}$ & $\begin{array}{c}\text { Social } \\
\text { non-specific } \\
\text { / ex post }\end{array}$ & $\begin{array}{l}\text { ranking exercise with } \\
\text { experimental design }\end{array}$ & $\begin{array}{l}\text { mean preferences: } \\
\text { (1) age: } 16 \text { > } 37 \text { > } 68 \\
\text { (2) healthy lifestyle: yes > no } \\
\text { (3) type of illness: acute > chronic } \\
\text { (4) severity of illness before treatment: } \\
\text { severe > light } \\
\text { (5) improvement in health after treatment: } \\
\text { large > middle > small } \\
\text { (6) treatment costs: low > medium> high } \\
\text { (not significant) } \\
\text { relative importance: } \\
\text { age: } 20.9 \% \\
\text { severity of illness before treatment: } 19.6 \% \\
\text { improvement in health after treatment: } \\
\text { 19.5\% } \\
\text { healthy lifestyle: } 15.3 \% \\
\text { treatment costs: } 13.5 \% \\
\text { type of illness: } 11.2 \%\end{array}$ \\
\hline
\end{tabular}




\section{Appendix 3 Summary of results on 'other attributes'}

\section{Other attributes of beneficiaries}

Four studies elicited preferences for beneficiaries who have dependents (Diederich, et al., 2012; Dolan and Shaw, 2003; Linley and Hughes, 2013; Norman, et al., 2013). Three suggest the general public tends to favour individuals with dependents over those without dependents (Diederich, et al., 2012; Linley and Hughes, 2013; Norman, et al., 2013). The other study ranked having dependents as one of the least important attributes (Dolan and Shaw, 2003). Two studies elicited preference for marital status. Charny, et al. (1989) suggested that married people were favoured over singles while Diederich, et al. (2012) found that singles were favoured over those who are married. Charny, et al. (1989) found both employment status and gender had no impact on resource allocation. Whitty, et al. (2014) reported indigenous people and those living in rural or remote areas were favoured.

Three studies elicited preference for QoL after treatment or the end health state (Bryan, et al., 2002; Roberts, et al., 1999; Whitty, et al., 2008). All suggest little support for health care programmes that may leave patients in relatively poor health states even though this represents a prognostic improvement. A similar attribute is treatment potential (i.e. the best possible end health state) and Ubel, et al. (1999) found that individuals with less treatment potential were not disfavoured even if their gain from treatment was very limited.

Two studies elicited preferences for the rarity of disease. Linley and Hughes (2013) reported that common diseases were favoured over rare diseases while Schwappach and Strasmann (2006) found that rarity of disease had no impact on resource allocation. 
Two studies elicited preferences for lifetime QALYs (i.e., health from a specific time to death). Bleichrodt et al (2005) and Edlin et al (2012) both found people with fewer lifetime QALYs were favoured. Similarly, Dolan and Tsuchiya (2005a) elicited preferences for past QALYs (i.e., health experienced up to now) and found people with fewer past QALYs were favoured. Another study by Dolan and Tsuchiya (2005b) elicited preferences for past QoL (i.e., QoL of all the past years) and found people with less past QoL were favoured. All four papers interpreted their results using fair inning arguments.

\section{Other contextual attributes}

Three studies elicited preferences for availability of alternative treatment and all found that a disease with no alternative treatment was given priority (Green and Gerard, 2009; Linley and Hughes, 2013; Whitty, et al., 2014). Linley and Hughes (2013) found this preference remained even when the treatment led to limited health gain. Other attributes include number of patients (3 studies: larger number is favoured) (Bryan, et al., 2002; Palanca-Tan, 2013; Whitty, et al., 2014), chance of success (3 studies: higher chance is favoured) (Bryan, et al., 2002; Whitty, et al., 2008; Whitty, et al., 2011), cost effectiveness (2 studies: more cost effective treatment is favoured) (Green and Gerard, 2009; Whitty, et al., 2014), and uncertainty in evidence (1 study: lower uncertainty in evidence is favoured) (Mortimer and Segal, 2008).

\section{Reference}

Bryan S, Roberts T, Heginbotham C, McCallum A. 2002. Qaly-maximisation and public preferences: Results from a general population survey. Health economics 11: 679-693.

Charny MC, Lewis PA, Farrow SC. 1989. Choosing who shall not be treated in the nhs. Social Science \& Medicine 28: 1331-1338.

Diederich A, Swait J, Wirsik N. 2012. Citizen participation in patient prioritization policy decisions: An empirical and experimental study on patients' characteristics. Plos One 7. 
Dolan P, Shaw R. 2003. A note on the relative importance that people attach to different factors when setting priorities in health care. Health Expectations 6: 53-59.

Green C, Gerard K. 2009. Exploring the social value of health-care interventions: A stated preference discrete choice experiment. Health economics 18: 951-976.

Linley WG, Hughes DA. 2013. Societal views on nice, cancer drugs fund and value-based pricing criteria for prioritising medicines: A cross-sectional survey of 4118 adults in great britain. Health economics 22: 948-964.

Mortimer D, Segal L. 2008. Is the value of a life or life-year saved context specific? Further evidence from a discrete choice experiment. Cost Effectiveness and Resource Allocation 6.

Norman R, Hall J, Street D, Viney R. 2013. Efficiency and equity: A stated preference approach. Health economics 22: 568-581.

Palanca-Tan R. 2013. Age preferences for life-saving programs: Using choice modeling to measure the relative values of statistical life. The Singapore Economic Review $\mathbf{5 8 .}$

Roberts T, Bryan S, Heginbotham C, McCallum A. 1999. Public involvement in health care priority setting: An economic perspective. Health Expectations 2: 235-244.

Schwappach DL, Strasmann TJ. 2006. "Quick and dirty numbers"? The reliability of a statedpreference technique for the measurement of preferences for resource allocation. Journal of Health Economics 25: 432-448.

Ubel PA, Richardson J, Prades JLP. 1999. Life-saving treatments and disabilities - are all qalys created equal? International Journal of Technology Assessment in Health Care 15: 738-748.

Whitty JA, Ratcliffe J, Chen G, Scuffham PA. 2014. Australian public preferences for the funding of new health technologies: A comparison of discrete choice and profile case best-worst scaling methods. Medical Decision Making 34: 638-654.

Whitty JA, Rundle-Thiele SR, Scuffham PA. 2008. Insights into public preferences for pharmaceutical funding. International Journal of Pharmaceutical and Healthcare Marketing 2: 216-234.

Whitty JA, Scuffham PA, Rundle-Thielee SR. 2011. Public and decision maker stated preferences for pharmaceutical subsidy decisions. Applied health economics and health policy 9: 73-79. 